\title{
Three rivers and a fish: body shape variation in adult inanga (Galaxias maculatus) and implications for reproductive output
}

\section{Vincent Benjamin Tait Wood}

A thesis submitted to Victoria University of Wellington in partial fulfilment of the requirement for the degree of Master of Science in Ecology and Biodiversity

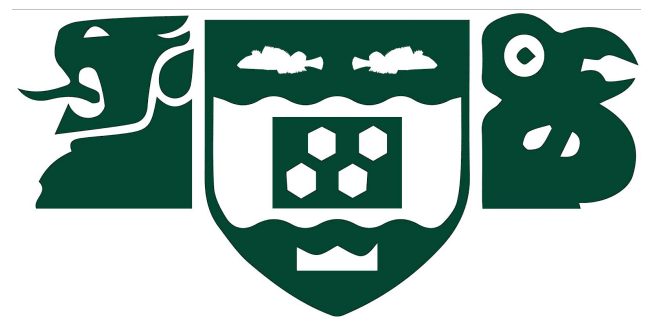

Victoria University of Wellington 2016 


\section{Abstract}

Inanga (Galaxias maculatus) are the major component of New Zealand's whitebait fisheries. Monitoring of freshwater-based adult populations in both North and South Island river systems suggests a general decline in numbers of fish, and specific streams and watersheds are of particular concern for some regional councils. Given this context, improved information about the environmental conditions that influence inanga's reproductive output may help to inform appropriate management actions and improve the long term viability of these populations. The breeding biology of adult inanga has been the focus of considerable research effort, with restoration of spawning grounds further extending our knowledge of spatio-temporal patterns of spawning. However, the behaviour patterns and fates of adult fish outside of the spawning locations and seasons are poorly known, as are the factors that may influence the survival and development of pre-spawning stages of inanga. Variation in body shape and size influences multiple performance and fitness attributes, and has major implications for reproduction. My thesis aims to quantify relationships between morphology and reproductive output for adult inanga, and to investigate environmental factors that may influence morphological development.

I collected inanga at two discrete stages of adult development: (i) pre-spawning stage adults at upstream habitats and (ii) spawning-stage adults collected at known breeding grounds during the spawning season. I photographed inanga in the field using a purpose-built aquarium and measured a set of morphological characteristics related to reproductive output and swimming ability. Specifically, I measured standard length, head depth, body depth and caudal peduncle depth. A subsample of adult inanga collected during the spawning season were returned to the laboratory and euthanized to measure aspects of their reproductive biology. Specifically, I measured reproductive output using gonad 
weight, I estimated maturity using the gonadosomatic index (GSI: weight of the gonad relative to total body weight), and I estimated energetic reserves using the hepatosomatic index (HSI: weight of the liver relative to total body weight).

Pre-spawning stage inanga in the Waiwhetu Stream displayed deeper bodies than fish in either the Hutt or Wainuiomata Rivers, potentially due to higher concentrations of food. Inanga in the Wainuiomata River displayed slightly larger sizes prior to the spawning season and substantially larger bodies during the spawning season. Although the Waiwhetu Stream may have had a greater supply of food, high densities of fish in smaller stream systems could constrain adult growth. Spawning-stage adults collected from the Waiwhetu Stream had greater reproductive output than fish collected from the Hutt River, with a peak in spawning activity during May. Fish collected from spawning grounds in the Hutt River had lower reproductive output and two peaks in spawning activity during March and May. Inanga in the Hutt River also displayed greater withinmonth variation in the maturity of fish.

My results suggest that spawning grounds in larger, more complex river systems (e.g., the Hutt River) may be supplied by inanga from a diverse range of main stem habitats and smaller tributaries further inland. Smaller systems (e.g., the Waiwhetu Stream) may be comprised of a more homogeneous population of inanga, and reproductive output of the system as a whole may be greater, but concentrated over a shorter time period. I hypothesise that the reproductive output from larger river systems may be more resilient to disturbance events (e.g., stock trampling of spawning grounds) because these systems (by virtue of their greater diversity of habitats and phenotypes of fish) may enable multiple opportunities for spawning. I suggest that larger rivers, such as the Hutt River, may be of disproportionate importance (independent of their total reproductive output) for the replenishment of inanga stocks. 


\section{Acknowledgements}

Firstly, I would like to thank my supervisor Jeff Shima. Your support and advice has been invaluable throughout my Master's degree. You always had an open door for discussion and continually pointed me in the direction of new ideas and questions to explore. To Jessie, Chris and Conor, the long hours of photographing and measuring fish were only possible with your assistance, both in the field and in the lab your company has been awesome. A special thank you to Conor for your indomitable spirit during the spawning season. We may have had to spend far more days sampling than planned but the sandwiches from the Shoreside Cafe made it well worth it!

To the Shima lab group, thank you for providing such a lively workplace, I've never encountered a group of people so dedicated to their pranks and morning tea. Cheers to Snout, Becky, Phoebe, Ben and Megan for your support around the lab and being a great group to start learning how to dive, you encouraged me to explore an aspect of Wellington I had not encountered before. To the VUCEL technicians, thank you for providing me with realistic alternatives to some of my plans that may not have been so feasible! My field work and data collection would have been most difficult without your advice. Thank you also to the Greater Wellington Regional Council for providing funding for my project, to Penny Fairbrother and Alton Perrie for providing local knowledge on rivers of interest around Wellington, and Mike Joy for lending me the nets used for sampling.

To my brother Jordan, your patience over the last two years has been immense, allowing me to talk about my project endlessly without once telling me to cut my chatter. Also to my parents, you always provided a home away from home to come back to when food and energy reserves were running low. Finally, this 
thesis would never have been completed without the continual support, feedback and encouragement from Mark Kaemingk. Your ideas for my initial study design, revision of my writing and continual interest in my project has been overwhelming; you have a true teacher's spirit. 


\section{Table of Contents}

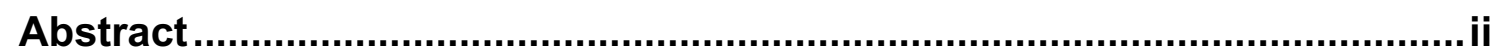

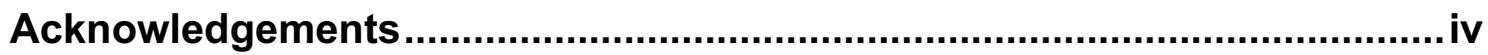

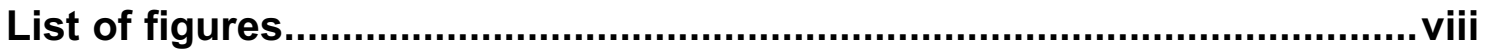

Chapter 1 - General introduction ............................................................

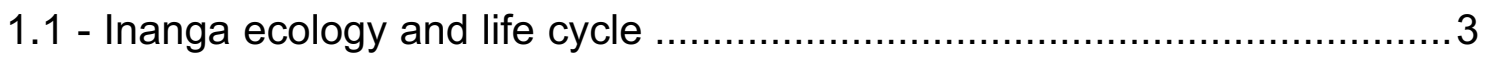

1.2 - Potential causes of variation in adult inanga morphology ...................... 6

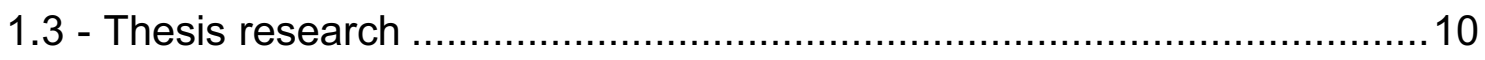

Chapter 2 - Spatio-temporal variation in the body shape of pre-spawn and spawning adult inanga (Galaxias maculatus) ........................................ 14

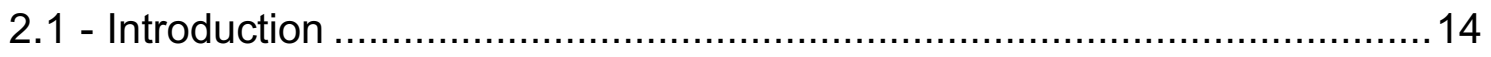

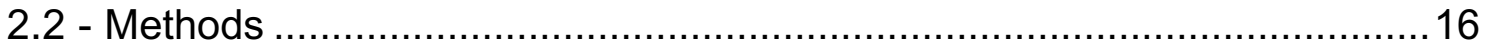

2.2.1 - Study system and field sampling ................................. 16

2.2 .2 - Quantifying morphology .................................................. 18

2.2.3 - Morphological variation within and among populations ........... 19

2.2.4 - Spatio-temporal variability in body shape through ontogeny....21

2.3 - Results 21

2.3.1 - Morphological variation within and among populations ...........22

2.3.2 - Spatio-temporal variability in body shape through ontogeny....25

2.4 - Discussion 28

2.4.1 - Variability in morphology of pre-spawn inanga .....................28

2.4.2 - Potential environmental factors influencing adult development 29 2.4.3 - Conclusions 31 
Chapter 3 - Changes in reproductive output and energetic reserves of adult inanga (Galaxias maculatus) during the spawning season

3.1 - Introduction 33

3.2 - Methods 35

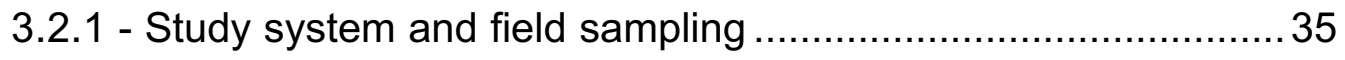

3.2.2 - Quantifying reproductive output and energetic reserves .......... 36

3.3.4 - Spatio-temporal variability in reproductive output and energetic reserves 38

3.4 - Results 39

3.4.1 - Spatio-temporal variability in reproductive output and energetic reserves 39

3.5 - Discussion 42

3.5.1 - Variability in reproductive output and energetic reserves. 42

3.5.2 - Potential environmental factors that influence reproductive output.

3.5.3 - Spawning patterns in regards to river size and complexity ...... 44

3.5.4 - Conclusions 46

Chapter 4 - General discussion 47

4.1 - Summary of findings 47

4.2 - Management of pre-spawning stage adult inanga populations .48

4.3 - Future directions and limitations of the present study .50

Bibliography. .53 


\section{List of figures and tables}

\section{Chapter 1 - General introduction}

Figure 1.1 - Lateral photograph of (a) pre-spawning stage adult inanga that has recently returned to freshwater from the sea, and (b) spawning stage adult collected during the breeding season. Small tick marks on scale bars indicate $\mathrm{mm}$.

\section{Chapter 2 - Spatio-temporal variation in the body shape of pre-spawn and spawning adult inanga (Galaxias maculatus)}

Figure 2.1 - Three-river study system showing sampling sites for pre-spawn adult inanga $(1,3,5)$ during December 2015 and spawning adults $(2,4,6)$ from March through June 2016.

Table 2.1 - Location of sampling sites and adult inanga developmental stage in the Wellington Region. Flow data collected by the Greater Wellington Regional Council (GWRC) and distance upstream measured along the course of the river in Google Earth.

Figure 2.2 - Lateral photograph of a pre-spawning stage inanga, solid white lines indicate linear measurements taken in ImageJ. SL: standard length (tip of snout to posterior vertebrae of caudal peduncle). HD: head depth (perpendicular to midline along anterior edge of operculum). BD: maximum body depth (perpendicular to midline from anterior edge of pectoral fin). CPD: caudal peduncle depth (narrowest point of caudal peduncle).

Figure 2.3 - Pre-spawning stage adult inanga (a) head depth, (b) body depth, and (c) caudal peduncle depth relative to body size (as measured by standard length; see Figure 2.2 for depiction of traits). Fitted lines reflect parameter estimates from analysis of covariance (ANCOVA) and associated $95 \%$ confidence bands. Standard length set as the covariate and site as a factor with three levels: Waiwhetu Stream (red), Wainuiomata River (blue), Hutt River (green).

Figure 2.4 - Variation in adult inanga (a) standard length, and (b) fineness ratio (standard length/body depth) in the Waiwhetu Stream (solid red line with circles), Hutt River (dashed green line with triangles) and Wainuiomata River (dashed blue line with squares). Pre-spawning stage adults sampled during December and spawning-stage adults sampled from March through June. Fish with high fineness ratios have shallower bodies. Spawning-stage adults were only collected during March in the Wainuiomata River. Mean value for each month plotted with average \pm SE (error bars). 


\section{Chapter 3 - Changes in reproductive output and energetic reserves of adult}

inanga (Galaxias maculatus) during the spawning season

Figure 3.1 - (a) Female adult inanga showing egg mass before removal and weighing, and (b) inanga liver on balance scales.

Figure 3.2 - Spawning adult inanga (a) gonad weight, (b) gonadosomatic index (\% of total body weight comprised of gonad), and (c) hepatosomatic index (\% of total body weight comprised of liver). Waiwhetu Stream (solid red line with circles) and Hutt River (dashed blue line with triangles). Given are mean values for each month and average \pm SE (error bars). The hepatosomatic index was not calculated for March as liver weights were only recorded from April through June. 



\section{Chapter 1 - General introduction}

Many fish that live in rivers display a diadromous life cycle, moving regularly between coastal streams and the sea (McDowall \& Croom, 1988; Crossin et al., 2004). Diadromous species provide important opportunities for both commercial and recreational fisheries, with fish targeted while at sea and/or in rivers, and as they make the transition from sea to river (where shoals of fish are funneled through constrained river mouths and can be caught in large numbers; Crossin et al., 2004; McDowall, 2010). Inanga (Galaxias maculatus) form the major component of New Zealand's whitebait fisheries (Barbee et al., 2011). New Zealand's main commercial fisheries for inanga operate along the west coast of the South Island, and consequently the majority of research on the species has been conducted in this region (McDowall, 1968; McDowall \& Croom, 1988; Stevens et al., 2016). Monitoring of freshwater-based adult populations in both North and South Island river systems suggests a general decline in numbers of fish, and specific streams and watersheds are of particular concern for some regional councils (Strickland \& Quarterman, 2001; Hickford \& Schiel, 2013). Given this context, improved information about environmental conditions that influence inanga's reproductive output may help to inform appropriate management actions and improve the long term viability of these populations.

Variation in body size and shape can influence individual performance and the reproductive output of adult life stages (Legendre et al., 1992; Jacquemin \& Pyron, 2013). Phylogeny constrains phenotypes and accounts for much of the phenotypic variation within and between species (Weaver \& Ingram, 1969). However, many organisms display some degree of phenotypic plasticity (Weaver \& Ingram, 1969; Grether, 2005; Daverat et al., 2006). Phenotypes also change with ontogeny and in addition, diadromous species of fish may undergo 
significant changes in body shape and physiology during the transition from salt to freshwater (Crossin et al., 2004; Edeline, 2007). Inanga display a high degree of morphological plasticity, with considerable variation in body size and shape within and between geographic regions (Barbee et al., 2011). Within-region morphological variation (i.e., variation over small spatial scales) has been attributed to differences in food supply, flow rate and predation (McDowall, 1968; Ferriz et al., 2001; Milano et al., 2010). Streams with low water flow and high concentrations of food appear to be the preferred habitat for developing inanga (McDowall, 1968; Jowett, 2002). Variation in body shape is known to affect the reproductive capabilities of many freshwater fish (McDowall \& Croom, 1988; Legendre et al., 1992). In general, larger and deeper bodied individuals have greater reproductive output (Legendre et al., 1992).

Inanga's breeding biology has been the focus of considerable research effort, and far more information is available on the freshwater adults than the oceanic larval stage (Barbee \& Swearer, 2007; Stevens et al., 2016). Restoration of lowland spawning habitats has also been a major objective for freshwater ecologists and regional councils, and these efforts have further extended our knowledge of spatio-temporal variation in spawning patterns (Strickland \& Quarterman, 2001; Hickford \& Schiel, 2013). However, the behaviour patterns and fates of adult fish outside of the spawning locations and seasons are poorly known, as are the factors that may influence the survival and development of pre-spawning stages of inanga in rivers. My thesis aims to address fundamental gaps in our knowledge by evaluating (1) relationships between adult inanga morphology and reproductive output, and (2) environmental factors that shape these patterns. 


\section{1 - Inanga ecology and life cycle}

Inanga are a small, diadromous fish with a wide geographic distribution throughout the southern hemisphere (Berra et al., 1997). Diadromy is a life cycle where part of the fish's life is spent in freshwater and part is in the ocean (Myers, 1949; McDowall \& Croom, 1988). Diadromous fish can be further categorised as (i) anadromous species that migrate from the sea to freshwater to spawn, (ii) catadromous species that migrate from freshwater to the sea to spawn, and (iii) amphidromous species that migrate for purposes other than breeding (McDowall \& Croom, 1988; Lucas, 2001). Inanga are classified as amphidromous because their migration is not exclusively for purposes of breeding (Barriga et al., 2002). While most inanga migrate to sea for a period of development, an oceanic migration is not required for inanga to complete their development and successfully reproduce (Hayes et al., 1989; Carrea et al., 2012).

Landlocked inanga inhabit several lakes and inland rivers of southern Chile and Argentina, with non-oceanic migrating populations also found throughout New Zealand (Barriga et al., 2002). Potential advantages of marine larval dispersal for amphidromous populations include access to planktonic marine resources for developing larvae (McDowall, 2010), and increased connectivity between river systems (which may vary in their quality or suitability through time) from a relatively unstructured oceanic larval pool (Hickford \& Schiel, 2016). Increased connectivity between streams may provide resilience in the event that adult populations become locally extirpated (McDowall, 2010). Alternatively, amphidromy may not provide significant benefits for some migratory populations, instead reflecting an ancestral trait of galaxiid species (McDowall, 2010).

The rate at which inanga migrate inland from the sea to adult habitats is nonuniform, with slow movement upstream immediately following return to freshwater and increasing movement as fish migrate further inland (Jung et al., 2009). The gradual upstream migration and delay in estuarine waters likely 
allows fish to change their osmoregulatory system to accommodate the freshwater environment (Jung et al., 2009). Inanga's upstream migration has significant energetic costs, and consequently there is high mortality among migrating fish (Richardson, 2000). During this transition period and upstream migration inanga may also undergo significant changes in their morphology related to selective pressures in the stream environment. Changes in body shape may be a result of either selective mortality on individuals with certain morphological traits (Persson, 1996), and/or inanga's high phenotypic plasticity and ability of individuals to undergo morphological changes in response to their environment (Ferriz et al., 2001).

Adult inanga live in shoals at upstream habitats, preferring slow flowing pool environments (McDowall, 1968). Inanga are primarily drift feeders, collecting small invertebrates that are carried downstream by the river (Jowett, 2002). Drift feeding is a technique used by many freshwater fish, whereby an individual holds a steady position in the current and collects food items from the water column (Rincon et al., 2007; Neuswanger et al., 2014). Inanga tend to select feeding habitats that maximise the delivery of food while minimising energetic loss from water drag (Jowett, 2002). While inanga appear to prefer streams with low flow, other galaxiid species such as koaro (Galaxias brevipinnis) are often found in fast flowing cascade and riffle habitats (McDowall \& Suren, 1995; Jowett, 2002). Koaro are morphologically adapted to high flow environments, with elongated bodies and enlarged pectoral fins that help fish cling to the riverbed (McDowall \& Suren, 1995).

In late summer to early autumn, adult inanga migrate downstream in large breeding shoals to spawn near the river mouth (at the saltwater wedge, the furthest inland penetration of saltwater at high tide) on high perigean spring or king tides (Stevens et al., 2016). McDowall (1968) found that adult inanga in slow flowing streams draining lowland forest and swamp regions had larger, deeper bodies and higher reproductive output than populations in large, fast 
flowing braided river systems. Spawning adults congregate near the saltwater wedge at high tide, and females then deposit their eggs amongst the bases of the damp riparian vegetation (McDowall, 1968). Inanga require a protective cover for their eggs to successfully develop (Hickford \& Schiel, 2013), and eggs are most frequently found along sections of the riverbank with thick grass and other vegetation (McDowall, 1968). Inanga in the Waikanae River primarily spawn amongst fescue (Festuca sp.) cocksfoot (Dactylis sp.) and clover (Trifolium sp.) (McDowall, 1968). Eggs are exposed to the air for 2-4 weeks, and rely upon the cover of vegetation to protect them from terrestrial predators (including snails, geckos and field mice) and desiccation by overexposure to ultraviolet radiation (Baker, 2006). Research in the Canterbury Region of the South Island has shown that the removal of riparian vegetation can strip the protective cover required for eggs to successfully develop, leading to widespread mortality of the developing larvae (Hickford \& Schiel, 2013).

Inanga spawning activity in New Zealand is greatest from January to May, with a proposed peak in spawning that is thought to occur in April and May in the South Island (Stevens et al., 2016). Records in the National Inanga Spawning Database indicate a later onset of the spawning season in the North Island compared with South Island populations. McDowall's work in the Waikanae River in the North Island indicates that spawning activity was highest from March-June (McDowall, 1968). Studies on egg density amongst riparian vegetation on the Waitetuna and Mokau rivers also suggest March-June as the peak breeding period for inanga in the North Island (Allibone, 2003; Baker, 2006).

Despite showing a peak in breeding activity during autumn, inanga have been recorded spawning during September in the Bay of Plenty (Graham, 1956) and eggs have been collected from riparian vegetation in late June by McDowall from the Makara Stream (McDowall, 1968). Spawning inanga have therefore been collected from September until June in the North Island, showing that the species is capable of spawning during most months of the year. Post-spawning mortality of adult inanga is close to $100 \%$, with few individuals surviving through to a 
second breeding season (Boy et al. 2009; McDowall, 1968). However, surveys of adult populations in the South Island have recorded individuals as old as three years, demonstrating that some inanga do survive beyond one year of age (Taylor et al., 1992). Furthermore, recent evidence has shown that some adult inanga spawn more than once, indicating that while the vast majority of spawning adults are semelparous, some individuals are iteroparous (Stevens et al., 2016). Reproductive output of a stream is therefore largely dependent on annual recruitment. Thus, annual marine recruits and freshwater development (somatic and reproductive growth) of these recruits is critically important for these populations.

\section{2 - Potential causes of variation in adult inanga morphology}

Sufficient food supply is critical for fish growth, and is a major determinant of body size and shape (Legendre et al., 1992; Barriga et al., 2012). Inanga are primarily drift feeders, maintaining a steady position in the water column and collecting small invertebrates carried downstream by the river (Jowett, 2002; Barriga et al., 2012). Drift feeding adult inanga are commonly observed in sections of the stream with relatively low water flow (Jowett, 2002). During a detailed study of inanga's reproductive biology and dietary preferences in the Waikanae River of the North Island, McDowall counted and attempted to identify 43,365 food items in the gut of adult inanga (McDowall, 1968). His analysis indicates a high diversity of food items are consumed by inanga; however, the three dominant aquatic food types were Copepoda (39.4\%), Chironomidae larvae and pupae (21.6\%) and gastropod molluscs from the Prosobranchiata order $(20.7 \%)$. Other important aquatic food items for adult fish include larvae from the Trichoptera order (5.7\%) and a range of unidentified fish eggs $(2.8 \%)$. Inanga also had several terrestrial species in their gut, including Coleoptera $(0.66 \%)$ and Hemiptera $(0.58 \%)$. McDowall's analysis suggests that while inanga are opportunistic feeders and will consume terrestrial insects that fall into the river, they predominantly feed on aquatic organisms, with the majority of their 
diet comprised of small freshwater invertebrates including crustaceans, snails and insect larvae (representing $81.7 \%$ of the total number of food items; McDowall, 1968). Streams with both high invertebrate biomass and low water flow likely maximise available food resources while minimising the energetic demands of drift feeding, and may result in larger, deeper bodied adult inanga.

Variation in flow rate can also produce intraspecific morphological variation among freshwater fish populations (Ferriz et al., 2001; Kovac, 2006; Haas, 2015). Differences in body shape that are correlated with flow rates may reflect an optimisation for swimming performance in environments with particular flow patterns (Haas, 2015). In general, fish display two primary swimming modes, steady and unsteady swimming (Langerhans \& Reznick, 2010). Steady swimming consists of locomotion at a constant speed over extended time periods and is often used for foraging through open-water habitats and long-distance migrations (Langerhans \& Reznick, 2010). Unsteady swimming involves a more complex array of locomotor abilities, with rapid changes in acceleration and direction. A deeper body shape can enhance fast-starts and avoidance of predatory strikes; however, this shape also provides substantial energetic disadvantages for steady swimming performance (Blob et al., 2010; Langerhans \& Reznick, 2010).

Freshwater fish in high flow environments often display small, fusiform bodies with deep heads that taper to a shallow caudal peduncle, or highly dorsoventrally compressed bodies that allow fish to hug the riverbed and reduce drag imposed by strong currents (Kovac, 2006; Langerhans \& Reznick, 2010). Fish in low flow environments do not require high drag reduction, and may develop stouter bodies with a deep posterior region that can generate thrust quickly allowing for rapid acceleration (Kovac, 2006). There is a hypothesised ecological tradeoff between a shallower body shape that optimises steady swimming performance, and a deeper body shape that optimises unsteady swimming performance (Langerhans \& Reznick, 2010). 
The effects of variation in stream flow on inanga morphology and swimming performance have been investigated in tributaries of the Limnay River basin in Argentina (Ferriz et al., 2001). Inanga displayed smaller, more robust bodies with deeper heads in high flow tributaries, and slender bodies with shallower heads in low flow tributaries. Ferriz's results contrast with the results of other studies on intraspecific variation in freshwater fish morphology in relation to stream flow (Kovac, 2006; Langerhans \& Reznick, 2010), suggesting inanga may display variable morphological responses to differences in flow. Alternatively, inanga may show low morphological plasticity in response to variation in flow rate. Although Ferriz ascribed variation in inanga morphology to a requirement for greater steady swimming performance in high flow environments, it is possible that variation in food supply and/or other factors in the stream environment may have been responsible for variation between populations. Intraspecific comparisons of freshwater fish living under variable flow regimes, however, do suggest a general trend towards a shallower body shape in higher flow environments (Langerhans \& Reznick, 2010).

Many of New Zealand's other native freshwater fish species display morphological adaptions to high flow environments (McDowall \& Suren, 1995; Duffy, 1996). Koaro (Galaxias brevipinnis) are also known as the climbing galaxias for their ability to scale waterfalls and steep concrete dams using enlarged pectoral fins (Duffy, 1996). Adult koaro have more elongated and shallower bodies than many of New Zealand's other diadromous galaxiids, presumably to reduce drag and facilitate their further inland penetration (McDowall \& Suren, 1995). While inanga are not known for their strong climbing abilities, koaro are capable of penetrating far inland, and generally inhabit faster flowing streams than inanga (McDowall \& Suren, 1995; Duffy, 1996). Inanga are most abundant in small, slow flowing pool habitats, allowing fish to collect food from the water column without expending a considerable amount of energy swimming against strong currents (Jowett, 2002). 
Predation is also related to intraspecific variation in both morphology and behaviour of freshwater fish (Persson, 1996; Milano et al., 2010). Many predatory fish are gape-limited, and can only consume prey items of a certain size class (Persson, 1996). Prey species that display rapid development of large, deep bodies may experience greater survival. Conversely, predatory fish may select for larger individuals, and prey populations subject to high predation may display smaller bodies than populations with low predator densities (Chang, 2005). Morphological variation in response to predators is often expressed through variation in head morphology, with variable responses depending on location and species (Milano et al., 2006). Some prey species develop larger heads and eyes in habitats with high predator densities, presumably to enhance the detection of predators (Langerhans \& Reznick, 2010). Prey species that inhabit high-predation intensity habitats may also develop a body shape that enhances predator avoidance (i.e. a deeper body that enhances unsteady swimming performance, allowing for greater acceleration and evasion of predatory strikes).

Inanga's ability to modify aspects of their morphology and reproductive biology has allowed this species to successfully persist in a diverse range of freshwater and marine habitats (McDowall, 2010). Slow flowing stream systems with high food supply likely provide optimal drift feeding habitats for adult inanga (Jowett, 2002), and result in larger, deeper bodied fish. Furthermore, inanga in high flow river systems may develop shallower bodies to improve steady swimming performance and reduce drag while drift feeding. Although a shallower body shape may be beneficial in high flow environments (Bernatchez \& Dodson, 1987; Langerhans \& Reznick, 2010; Walker et al., 2013), there may be negative impacts on reproductive output (Legendre et al., 1992). In general, larger, deeper-bodied adult fish have higher reproductive capabilities. Morphological differences among freshwater adult populations due to local environmental variation may have large implications for the reproductive output of spawning adult inanga. 


\section{3 - Thesis research}

To investigate relationships between fish body shape, reproductive output and environmental conditions, I sampled fish from three qualitatively different riverine systems. Streams with low water flow and high food supply appear to be the preferred habitat for developing inanga (McDowall, 1968; Jowett, 2002), and rivers were selected based on clear differences in mean flow $\left(\mathrm{m}^{3} / \mathrm{s}^{-1}\right)$. Although differences in flow are hypothesised to produce variation among populations, determining a causal relationship between flow and body shape is beyond the scope of this study. Streams also varied in several other aspects that could influence morphological development, including food supply, water quality and predation intensity (Strickland \& Quarterman, 2001; Perrie et al., 2012).

The three riverine systems sampled in this thesis are the Hutt River, the Waiwhetu Stream and the Wainuiomata River. The Hutt River is a large, braided river system with high flow and a rocky riverbed. Surveys by the Greater Wellington Regional Council indicate low numbers of inanga in the Hutt River (Strickland \& Quarterman, 2001). The Waiwhetu Stream is a small urban stream with low flow and high streambed cover of aquatic plants. Previous surveys in the Waiwhetu Stream indicate high numbers of inanga, suggesting the stream may have a high supply of food for developing adult populations (Strickland \& Quarterman, 2001).

The Waiwhetu Stream is also a polluted system, particularly in the lower reaches that pass through the industrial section of Gracefield (Perrie et al., 2012). Pollution can negatively affect the growth, morphology and reproductive output of freshwater fish (Al-Ghais, 2013), and may also influence the development and breeding biology of adult inanga. However, inanga are relatively resilient to low water quality (Jellyman \& Harding, 2014), and sizable adult populations are found in polluted urban streams throughout New Zealand (McDowall, 1968). It is possible that inanga's short residence in freshwater and regular oceanic 
migration minimises the build-up of contaminants in body tissues. The Hutt River and the Waiwhetu Stream share a river mouth that opens onto the Wellington Harbour at Petone. Consequently, both watersheds are likely to be replenished by juvenile fish with (initially) similar morphological traits.

The Wainuiomata River is of intermediate size and flow rate between the Hutt River and the Waiwhetu Stream, and opens onto Wellington's south coast. Previous sampling (Kaemingk \& Shima, unpub) suggests that the juvenile inanga that replenish the Wainuiomata River are larger, younger and faster growing than juvenile inanga sampled from the Hutt River. The Wainuiomata River primarily runs through agricultural land, and has a patchily distributed streambed cover of aquatic plants. Little information is available on the current adult population size in the Wainuiomata River. However, several records of inanga are found in the New Zealand Freshwater Fish Database, and trout fishermen regularly report observing brown trout chasing shoals of adult inanga in the river during summer.

To measure morphological changes associated with ontogeny, I collected adult inanga at two discrete stages of adult development from each stream: (1) prespawning stage adults that had recently migrated upstream (fish were collected during December, immediately following the main whitebait runs from AugustNovember), and (2) spawning-stage adults sampled at known spawning locations during the breeding season (Fig. 1.1). I hypothesised that prespawning stages would show relatively small variability in body shape, and that morphological differences within and between streams may increase as inanga develop further and experience (potentially selective) mortality in the lead-up to the spawning season. I expected inanga to display deep bodies in the Waiwhetu Stream, moderate body depths in the Wainuiomata River and shallow bodies in the Hutt River. Adult populations with shallower bodies were predicted to have lower energetic reserves and reproductive output during the spawning season. 

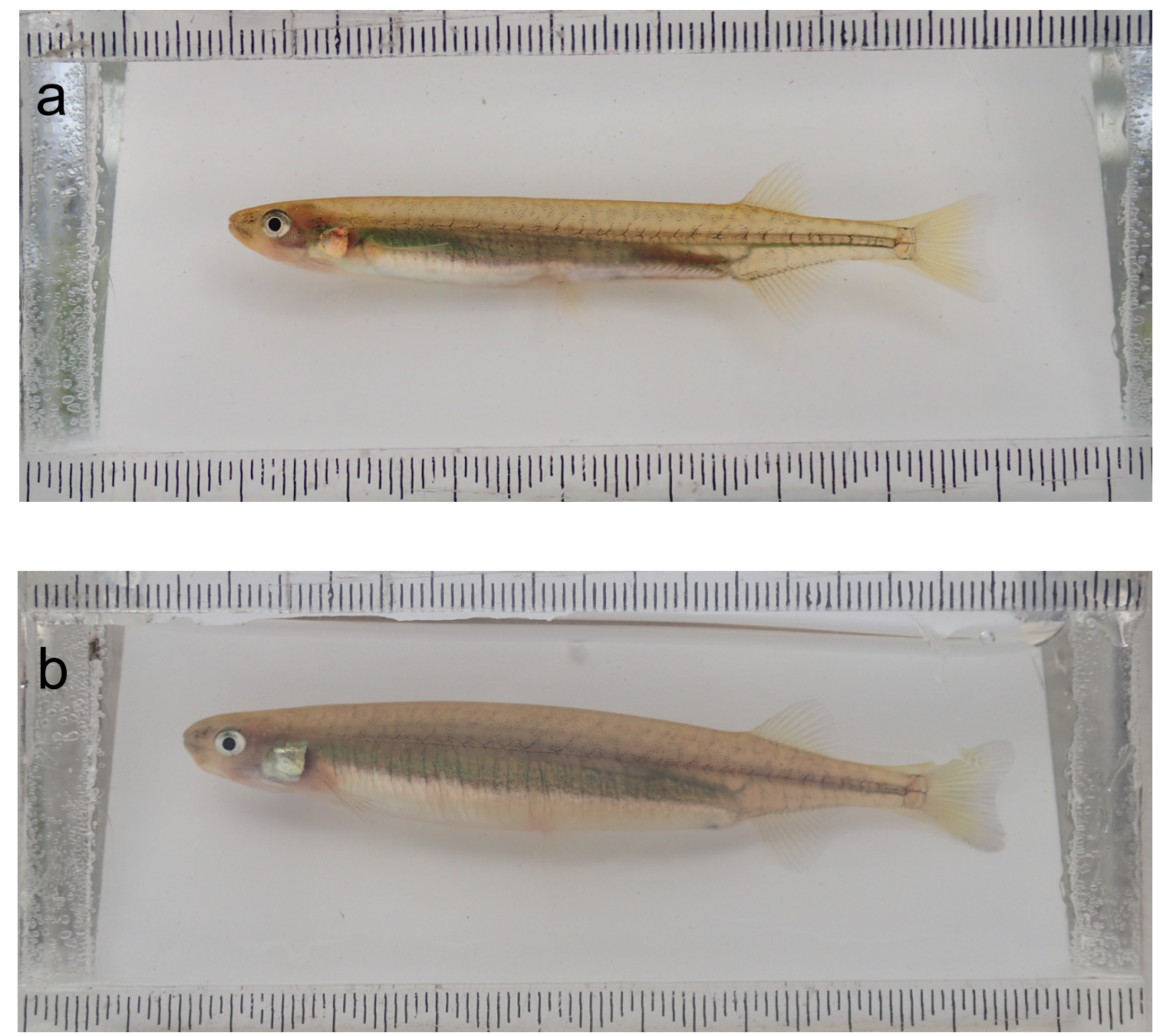

Figure 1.1 - Lateral photograph of (a) pre-spawning stage adult inanga that has recently returned to freshwater from the sea, and (b) spawning stage adult collected during the breeding season. Small tick marks on scale bars indicate $\mathrm{mm}$.

My thesis consists of two data chapters, which I have prepared as stand-alone manuscripts to facilitate eventual publication (i.e., these chapters have their own introduction and discussion sections). Consequently, there may be some overlap in information across chapters. In chapter 2, I evaluate spatio-temporal variation in the morphology of pre-spawning stages and spawning-stages of adult inanga populations. I also explore some environmental factors that may contribute to the observed patterns. In chapter 3, I quantify variability in reproductive output and energetic reserves of adult inanga at intervals across their spawning period. 
More specifically, I evaluate the potential relationship between morphological variation and reproductive output across stream systems. In chapter 4, I present a general discussion of my results; and consider how my results may inform management. I also outline some limitations of my study, and suggest some promising future research directions. 


\section{Chapter 2 - Spatio-temporal variation in the body shape of pre-spawn and spawning adult inanga (Galaxias maculatus)}

\section{1 - Introduction}

Variation in body size and shape influences individual performance and the reproductive output of adult life stages (Legendre et al., 1992; Jacquemin \& Pyron, 2013). While phylogeny constrains and accounts for a large portion of morphological variation within and among species, many organisms also display some degree of phenotypic plasticity (Weaver \& Ingram, 1969; Grether, 2005; Daverat et al., 2006). Species with greater phenotypic plasticity may be more capable of morphological and/or behavioral changes that are better suited to particular habitats (Grether, 2005; Edeline, 2007). Migratory species often display high phenotypic plasticity and undergo significant changes in body shape and physiology during transitions into new environments (Crossin et al., 2004).

Inanga (Galaxias maculatus) are a small, migratory fish that form the main component of New Zealand's whitebait fishery (Berra et al., 1997). The majority of coastal stream populations are amphidromous, with a marine larval stage and a freshwater adult stage (Hayes et al., 1989; McDowall, 2010). Adult inanga display high phenotypic plasticity, with considerable variation in both morphology and reproductive biology within and among streams (Barbee et al., 2011; Barriga et al., 2012). The morphology of whitebait collected from different regions of New Zealand is also known to vary considerably, with the largest juveniles commonly found on the west coast of the South Island (McDowall, 1968). Juvenile inanga return to coastal rivers after approximately 4-6 months of development in the marine environment and migrate upstream to adult habitats (Barbee \& Swearer, 
2007). Adult inanga are most abundant in small coastal streams with low water flow and high cover of both overhanging and aquatic vegetation (McDowall, 1968; Jowett, 2002). Prior to their spawning season, most inanga live in upstream shoals and drift feed, maintaining a steady position in the current and collecting small invertebrates carried downstream by the river (McDowall, 1968; Jowett, 2002). Slow flowing streams are likely favored by adult fish due to greater accumulation of food and reduced energetic demands of foraging (Jowett, 2002).

During autumn, inanga migrate downstream in large breeding shoals to spawn near the saltwater wedge (the furthest inland penetration of saltwater at high tide) (Barbee et al., 2011; Stevens et al., 2016). McDowall (1968) found that spawning inanga in smaller, low-flow systems tended to have larger, deeper bodies and higher fecundities. In contrast, inanga that spawned in larger, fasterflowing river systems tended to display smaller body sizes and lower fecundities (McDowall, 1968). This may occur because stream habitats with lower flow rates and higher concentrations of food constitute more productive environments for developing inanga populations during the pre-spawning season (although population densities may mediate this effect). In addition to the likelihood of a direct relationship between per capita food availability and gamete production, variation in inanga body shape (which may be caused by differing environmental conditions) may further constrain the reproductive output of spawning adult stages (i.e., smaller shallower bodies hold fewer eggs). Determining the factors that influence reproductive output is a key objective for both fundamental and applied ecological research (Legendre et al., 1992; Araki, 2009).

Here, I quantify the morphology of adult inanga sampled from three streams in the Wellington Region. Specifically, I targeted adults at two discrete stages of adult development: (1) pre-spawning adult stages that had recently migrated upstream (fish were collected during December, immediately following the main whitebait runs from August-November), and (2) spawning-stage adults sampled at known spawning locations during the breeding season. I hypothesised that 
adult inanga prior to the spawning season would show relatively small variability in body shape, and that morphological differences within and among streams may increase as inanga develop further, and experience (potentially selective) mortality in the lead-up to the spawning season. I anticipated that adult populations with deeper bodies would display greater reproductive output during the spawning season. My first objective for this chapter is to characterise the initial patterns of variation in body shape of pre-spawn inanga within and among streams. Secondly, I evaluate ontogenetic changes in morphological traits, and in particular, how these vary among streams with qualitatively different environmental conditions (e.g., developmental changes due to plasticity and/or selective mortality).

\section{2 - Methods}

\subsection{1 - Study system and field sampling}

I sampled inanga from three streams in the Wellington Region that differed qualitatively in a number of ways (see Chapter 1 ). Of particular interest were the clear differences in mean flow (Table 2.1), as previous studies have suggested a correlation between flow rate and the morphology of freshwater fish (Ferriz et al., 2001; Kovac, 2006). I expected that adult inanga collected from streams with greater flow would display shallower bodies. While streams vary significantly in flow regime, they also vary significantly in other environmental conditions that could influence morphology, including food supply, water quality and predation intensity (Strickland \& Quarterman, 2001; Perrie et al., 2012).

I sampled pre-spawning stages of inanga at inland sites during December 2015, following the main freshwater migrations from August to November (McDowall, 1968). I collected inanga from the furthest recorded inland penetration of adult shoals in each stream, as I expected that morphological variation between streams may be more pronounced further inland. Catch records in the New 
Zealand Freshwater Fish Database were used to estimate inanga's furthest inland penetration in each stream (NIWA, 2016). As a result of this procedure, the collection site for each stream varied in its distance from the sea (Fig. 2.1). I sampled spawning adult stages at monthly intervals (from March-June 2016) at lowland breeding grounds (leaving a 3-month gap for development from prespawn adult stages). For all collections, I used two Southland sock nets (large fyke nets with mouth opening $1.3 \mathrm{~m} \times 1.02 \mathrm{~m}$, length $3.5 \mathrm{~m}$ ). Nets were deployed within $2 \mathrm{~m}$ of the riverbank and spaced approximately $20 \mathrm{~m}$ apart, and were checked on half-hour or hourly intervals for approximately 6 hours (or until I obtained a sample size of $\sim 80$ fish).

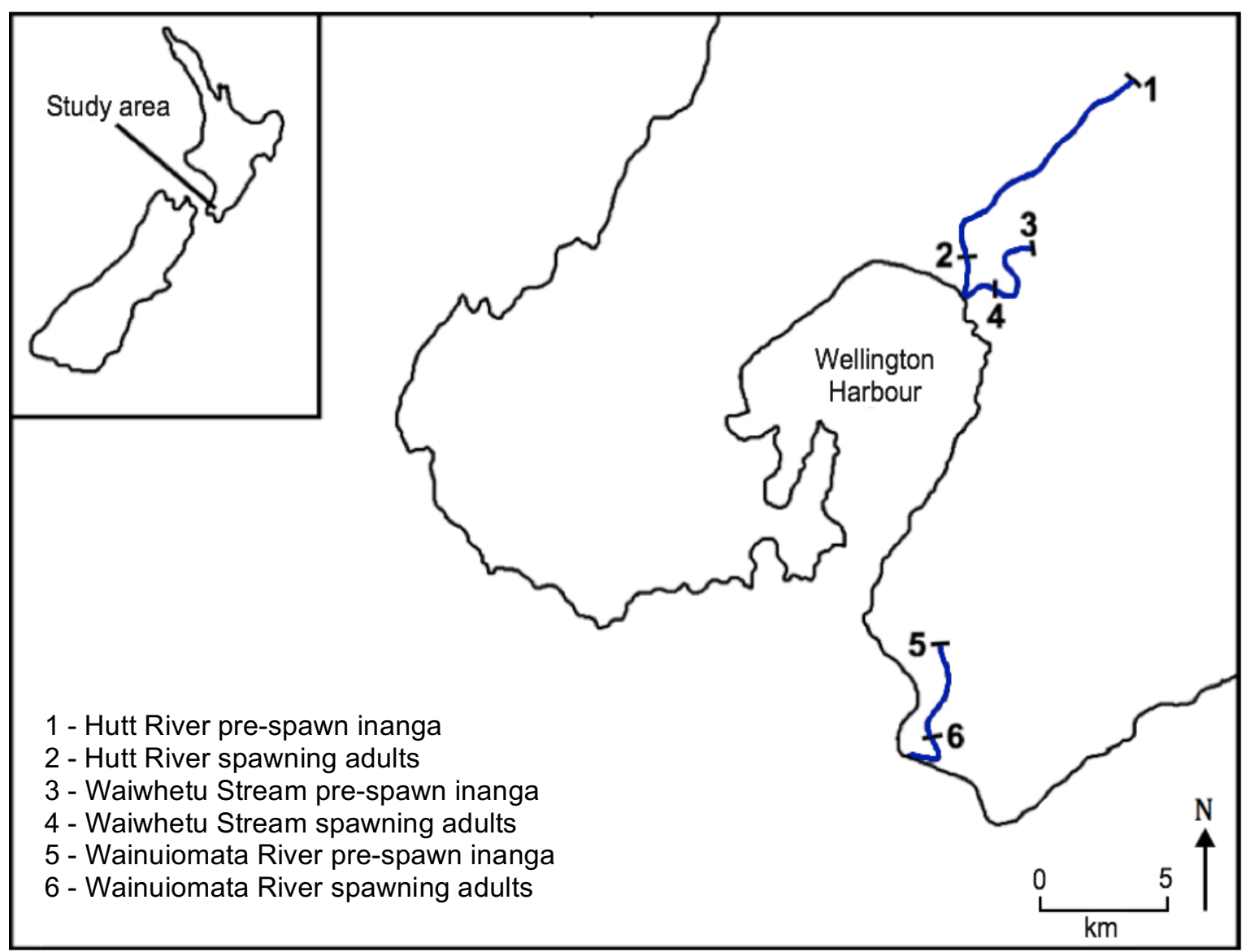

Figure 2.1 - Three-river study system showing sampling sites for pre-spawn adult inanga $(1,3,5)$ during December 2015 and spawning adults $(2,4,6)$ from March through June 2016. 


\begin{tabular}{|c|c|c|c|c|}
\hline Site & GPS & $\begin{array}{l}\text { Developmental } \\
\text { stage }\end{array}$ & $\begin{array}{l}\text { Distance } \\
\text { upstream (km) }\end{array}$ & $\begin{array}{l}\text { Flow } \\
\left(\mathrm{m}^{3} / \mathrm{s}^{-1}\right)\end{array}$ \\
\hline 1 - Hutt River & $\begin{array}{l}-41.19 \mathrm{~S} \\
174.94 \mathrm{E}\end{array}$ & Pre-spawn adults & 12 & 25.81 \\
\hline 2 - Hutt River & $\begin{array}{l}-41.22 \mathrm{~S} \\
174.90 \mathrm{E}\end{array}$ & Spawning adults & 3.8 & 25.81 \\
\hline $\begin{array}{l}3 \text { - Waiwhetu } \\
\text { Stream }\end{array}$ & $\begin{array}{l}-41.22 \mathrm{~S} \\
174.92 \mathrm{E}\end{array}$ & Pre-spawn adults & 6.1 & 0.22 \\
\hline $\begin{array}{l}4 \text { - Waiwhetu } \\
\text { Stream }\end{array}$ & $\begin{array}{l}-41.23 \mathrm{~S} \\
174.92 \mathrm{E}\end{array}$ & Spawning adults & 1.5 & 0.22 \\
\hline $\begin{array}{l}5 \text { - Wainuiomata } \\
\text { River }\end{array}$ & $\begin{array}{l}-41.38 \mathrm{~S} \\
174.89 \mathrm{E}\end{array}$ & Pre-spawn adults & 2.1 & 2.11 \\
\hline $\begin{array}{l}6 \text { - Wainuiomata } \\
\text { River }\end{array}$ & $\begin{array}{l}-41.41 \mathrm{~S} \\
174.88 \mathrm{E}\end{array}$ & Spawning adults & 3.5 & 2.11 \\
\hline
\end{tabular}

Table 2.1 - Location of sampling sites and adult inanga developmental stage in the Wellington Region. Flow data collected by the Greater Wellington Regional Council (GWRC) and distance upstream measured along the course of the river in Google Earth.

\subsection{2 - Quantifying morphology}

I photographed live inanga from each site in the field using an Olympus TG3 camera and a small, portable aquarium $(10 \mathrm{~cm}$ by $10 \mathrm{~cm})$. The purpose-built aquarium had an adjustable compartment to hold fish in a fixed focal plane, and two scale bars for reference attached to the front panel. Each sampled individual was photographed three times, with the clearest lateral photograph used for morphometric analysis (Fig. 2.2). A sub-sample of spawning-stage adults were returned to the laboratory and euthenised to measure reproductive output, and the remainder of fish were re-released to collection sites unharmed. I measured a set of morphological traits that are correlated with reproductive output (Reiss \& Grothues, 2015) and swimming performance (Langerhans \& Reznick, 2010; 
Walker et al., 2013) Linear measurements of standard length (SL), head depth $(\mathrm{HD})$, body depth $(\mathrm{BD})$ and caudal peduncle depth (CPD) were made from photographs using image analysis software (ImageJ version 1.49u; see Fig. 2.2 for depiction and additional detailing of measurements).

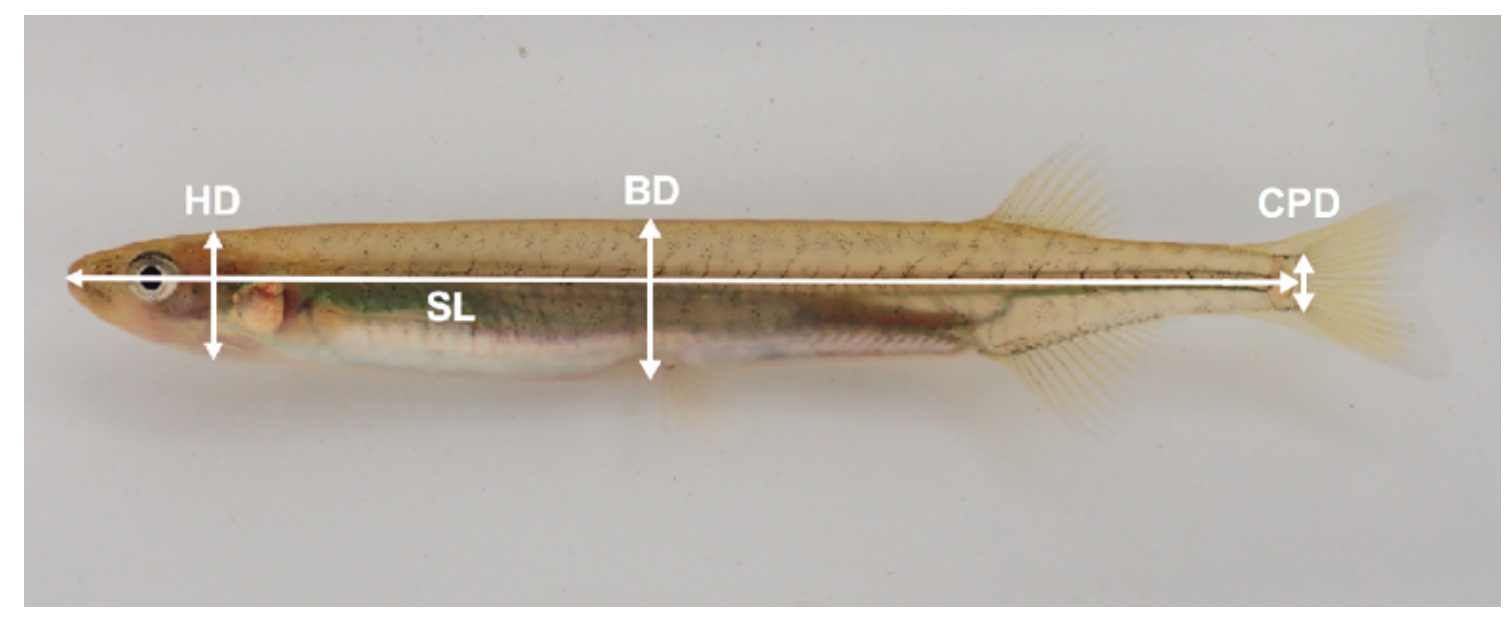

Figure 2.2 - Lateral photograph of a pre-spawning stage inanga, solid white lines indicate linear measurements taken in ImageJ. SL: standard length (tip of snout to posterior vertebrae of caudal peduncle). HD: head depth (perpendicular to midline along anterior edge of operculum). BD: maximum body depth (perpendicular to midline from anterior edge of pectoral fin). CPD: caudal peduncle depth (narrowest point of caudal peduncle).

\subsection{3 - Morphological variation within and among populations}

I evaluated variation in the average size of pre-spawning stage inanga sampled from the Hutt River, Waiwhetu Stream and Wainuiomata River using a one-way analysis of variance (ANOVA). I evaluated assumptions of normality and homogeneity of variance using residuals vs fitted and quantile-quantile ( $Q-Q)$ plots. I used a post-hoc Tukey test to run pairwise comparison of streams.

I evaluated spatial variation in other morphological traits with respect to body size (as measured by standard length). Most fish exhibit allometric growth, with nonlinear development of different body parts with increasing size (Mccoy, 
2006). I evaluated potential allometric relationships for measured traits by visual inspection of scatterplots (of trait vs standard length). Because this approach indicated linear relationships between traits and standard length (see results), I inferred isometric growth of measured traits (and this may be a reasonable assumption for a short-lived fish). Consequently, I used linear models to evaluate spatial variation in morphological traits with respect to fish size. Specifically, I used analysis of covariance (ANCOVA) to test for differences among fish collected from the three streams, in terms of each trait (i.e., head depth, body depth and caudal peduncle depth), while controlling for variation in standard length among fish. ANCOVA combines elements of analysis of variance (ANOVA) with linear regression, and relies on assumptions of linearity, normality and homogeneity of variance. I evaluated the three morphological traits in separate analyses. For each analysis, standard length was set as the covariate, stream was included as a fixed categorical factor with three levels (Hutt, Waiwhetu and Wainuiomata), and I included the interaction between SL and stream. Plotted data indicated relatively low morphological variation between streams, so I used partial eta squares (partial $\eta^{2}$ ) to estimate the relative effect size of 'stream' on each morphometric variable (head depth, body depth and caudal peduncle depth) by excluding the variation explained by the covariate (standard length).

Partial $\eta^{2}=S_{\text {between }} / \mathrm{SS}_{\text {between }}+\mathrm{SS}_{\text {error }}$

I used existing guidelines to classify the partial $\eta^{2}$ effect size as small, moderate or large (Miles \& Shevlin, 2001). A partial eta squared score close to 0.01 indicates a small effect size, 0.06 a moderate effect size and 0.14 a strong effect size (i.e. a partial $\eta^{2}$ of 0.05 indicates a moderate effect size where $\sim 5 \%$ of the variation in the metric of interest is explained by the given variable when the variation explained by other predictors in the model are accounted for). 


\subsection{4 - Spatio-temporal variability in body shape through ontogeny}

I evaluated ontogenetic changes in morphological traits, and in particular, how these vary among streams with qualitatively different environmental conditions. Specifically, I evaluated variation in standard length (SL; an overall measure of body size) and a calculated 'fineness ratio' (a measure of overall body depth standardised by fish size). Fish with high fineness ratios have a shallower body shape, whereas fish with low fineness ratios have deeper bodies (Langerhans \& Reznick, 2010; Walker et al., 2013). I calculated fineness ratio as BD:SL (after Walker et al., 2013). I used two-way ANOVAs to test for significant differences in these metrics (using separate analyses for each metric) between streams and sampling months (and I included the interaction of these two effects in my model). I used post hoc Tukey tests to evaluate differences between streams within each sampling month. Morphometric data was analysed in $\mathrm{R}$ Studio Version 0.99.484 using the R package stats 3.3.1. The Ggplot2 package was used for plotting and presentation of results.

\section{3 - Results}

I captured, photographed and measured the morphology of 766 pre-spawning stage adults in December $(n=346$ from Waiwhetu Stream, $n=132$ from Hutt River, $\mathrm{n}=288$ from Wainuiomata River). I captured, photographed and measured the morphology of 192 spawning stage adults from March-June ( $\mathrm{n}=$ 135 from Waiwhetu Stream, $n=37$ from Hutt River, $n=20$ from Wainuiomata River). Standard length of pre-spawning stage adults ranged from 3.288 $6.976 \mathrm{~cm}$. Standard length of spawning-stage adults ranged from 4.716 $8.903 \mathrm{~cm}$. A sub-sample of spawning-stage adults were returned to the laboratory to measure reproductive output and the remainder of fish were re-released to collection sites unharmed. 
One exceptionally large inanga was caught in the Wainuiomata River and three in the Waiwhetu Stream. These larger individuals are thought to be 2+ year old fish that may have survived from a prior breeding season, similar to the findings of McDowall in the Waikanae River (McDowall, 1968), and from freshwater streams near Christchurch and Westport in the South Island (Stevens et al., 2016). As these larger fish are unlikely to have migrated upstream during the previous whitebait season they were excluded from further analyses.

\subsection{1 - Morphological variation within and among populations}

Standard length of adult inanga varied significantly among pre-spawning stage populations $\left(F_{2,759}=26.003, p=<0.0001\right)$. Post-hoc Tukey tests indicated no significant difference in standard length between the Hutt River and Waiwhetu Stream $(p=0.5907)$. Fish sampled from the Wainuiomata River had longer standard lengths than either the Hutt River or the Waiwhetu Stream $(p=<0.0001$ for each). Average size of pre-spawn inanga was $4.905 \mathrm{~cm}$ in the Waiwhetu Stream, $4.944 \mathrm{~cm}$ in the Hutt River and $5.266 \mathrm{~cm}$ in the Wainuiomata River.

Head depth increased with standard length of fish (Fig. 2.3a: $F_{1,756}=6043.099$, $p$ <0.0001). Head depth varied among streams (Fig. 2.3a: $F_{2,756}=91.361, p$ $<0.0001)$, however, there was a significant interaction of standard length and stream on head depth (Fig. 2.3a: $F_{2,756}=15.593, p=<0.0001$, partial $\eta^{2}=$ 0.0396), indicating that fish from different streams had a different relationship between head depth and body size. Larger inanga had deeper heads in the Waiwhetu Stream, moderate head depths in the Wainuiomata River and shallow heads in the Hutt River. The effect size of stream on head depth was moderate ( $4 \%$ of variation in head depth explained by stream when variance explained by standard length accounted for).

Body depth increased with standard length of fish (Fig. 2.3b: $F_{1,756}=9790.489$, $p<0.0001$ ). Body depth varied among streams (Fig. 2.3b: $F_{2,756}=42.588, p$ 
$<0.0001$ ), however, there was a significant interaction of standard length and stream on body depth (Fig. 2.3b: $F_{2,756}=36.887, p<0.0001$, partial $\eta^{2}=0.0889$ ), indicating that fish from different streams had a different relationship between head depth and body size. The effect size of stream on body depth was moderate ( $9 \%$ of variation in body depth explained by stream when variance explained by standard length accounted for).

Caudal peduncle depth increased with standard length of fish (Fig. 2.3c: $F_{1,756}=$ 4566.4766, $p$ <0.0001). Body depth varied among streams (Fig. 2.3a: $F_{2,756}=$ 5.3886, $p<0.0047$ ), however, there was a significant interaction of standard length and stream on caudal peduncle depth (Fig. 2.3c: $F_{2,756}=3.4696, p=$ 0.0316 , partial $\eta^{2}=0.0091$ ), indicating that fish from different streams had a different relationship between caudal peduncle depth and body size. The effect size of stream on caudal peduncle depth was small $(<1 \%$ of variation in caudal peduncle depth explained by stream when variance explained by standard length accounted for). 

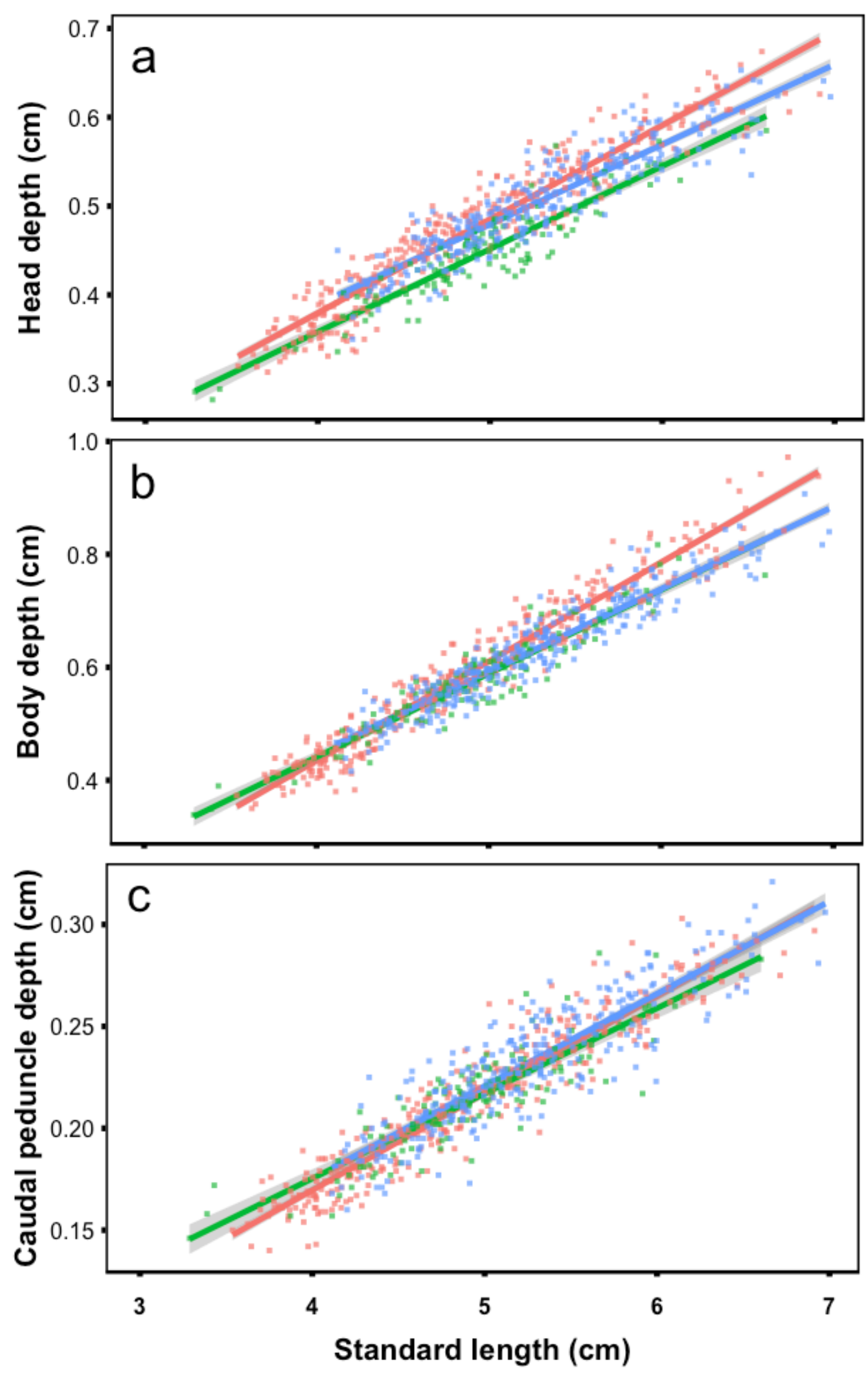

Figure 2.3 - Pre-spawning stage adult inanga (a) head depth, (b) body depth, and (c) caudal peduncle depth relative to body size (as measured by standard length; see Figure 2.2 for depiction of traits). Fitted lines reflect parameter estimates from analysis of covariance (ANCOVA) and associated $95 \%$ confidence bands. Standard length set as the covariate and site as a factor with three levels: Waiwhetu Stream (red), Wainuiomata River (blue), Hutt River (green). 


\subsection{2 - Spatio-temporal variability in body shape through ontogeny}

Spawning adults were only collected during March in the Wainuiomata River, and inanga were not observed in the river for the remainder of the spawning season. Therefore, data on standard length and fineness ratio in the Wainuiomata River is only available for December and March.

Standard lengths of sampled inanga varied among streams (Fig. 2.4a: $F_{2,942}=$ $12.639, p<0.0001)$. Standard lengths of fish also varied across months and/or ontogenetic stages (Fig. 2.4a: $F_{4,942}=116.137, p<0.0001$ ). However, there was a significant interaction between stream and sampling month on standard length (Fig. 2.4a: $F_{5,942}=11.630, p<0.0001$ ), indicating that the differences in body size among streams depended upon sampling month (and/or ontogenetic stage). Pre-spawning stages of inanga were only sampled in December, and not surprisingly, these fish tended to be shorter, on average, than spawning adults that were sampled later (and this pattern held for all streams, and for spawning stage adults sampled between March and June).

Post hoc Tukey tests for collections made in December indicate larger prespawning stage inanga in the Wainuiomata River compared with both the Hutt River $(p=0.0006)$ and the Waiwhetu Stream $(p<0.0001)$. Fish sampled from the Hutt River and Waiwhetu Stream in December were similar in size $(p=$ 0.9999). In March, fish sampled from the Wainuiomata River were longer than fish from the Hutt River $(p<0.0001)$ and from the Waiwhetu Stream $(p<0.0001)$. Inanga were also longer in the Waiwhetu Stream compared with the Hutt River in March $(p<0$.0001). There was no significant difference in the size of spawning adults between the Hutt River and the Waiwhetu Stream in April ( $p=$ $0.8594)$ and May $(p=0.9924)$. In June spawning adults were significantly larger in the Hutt River compared with the Waiwhetu Stream $(p<0.0001)$. 
Fineness ratios of sampled inanga varied among streams (Fig. 2.4b: $F_{2,942}=$ 13.995, $p<0.0001)$. Fineness ratios of fish also varied across months and/or ontogenetic stages (Fig. 2.4b: $F_{4,942}=31.1832$, $p<0.0001$ ). However, there was a significant interaction of stream and sampling month on fineness ratio (Fig. 2.4b: $F_{5,942}=7.0024, p<0.0001$ ), indicating that the differences in fineness ratio among streams depended upon sampling month (and/or ontogenetic stage).

Post hoc Tukey tests for collections made in December indicate higher fineness ratios for pre-spawning stage inanga in the Hutt River compared with both the Waiwhetu Stream $(p<0.0001)$ and the Wainuiomata River $(p<0.0001)$. Fish sampled from the Wainuiomata River and the Waiwhetu Stream in December had similar fineness ratios $(p=0.6413)$. Fish sampled during March displayed similar fineness ratios in all streams ( $p>0.05$ for all pairwise comparisons). Fish collected during March, April and June also displayed similar fineness ratios in all streams ( $p>0.05$ for all pairwise comparisons). In May spawning stage adults had significantly lower fineness ratios in the Waiwhetu Stream compared with the Hutt River $(p<0.0001)$. Although fineness ratios were not significantly different between streams in March, April and June, inanga in the Hutt River consistently displayed slightly higher fineness ratios (shallower bodies) than inanga in both the Wainuiomata River and the Waiwhetu Stream in all sampling months. 

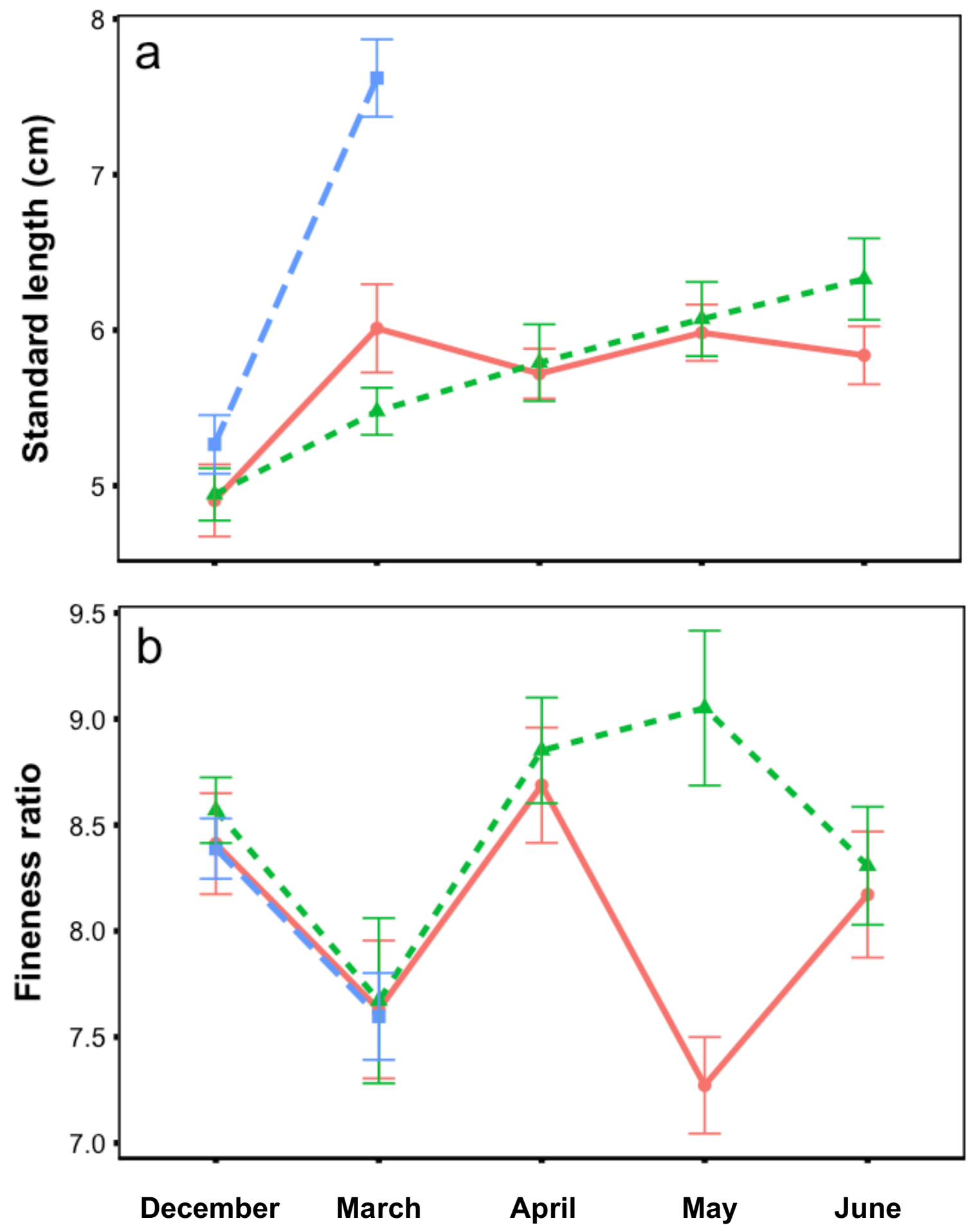

Figure 2.4 - Variation in adult inanga (a) standard length, and (b) fineness ratio (standard length/body depth) in the Waiwhetu Stream (solid red line with circles), Hutt River (dashed green line with triangles) and Wainuiomata River (dashed blue line with squares). Pre-spawning stage adults sampled during December and spawning-stage adults sampled from March through June. Fish with high fineness ratios have shallower bodies. Spawning-stage adults were only collected during March in the Wainuiomata River. Mean value for each month plotted with average \pm SE (error bars). 


\section{4 - Discussion}

\subsection{1 - Variability in morphology of pre-spawn inanga}

Pre-spawning stages of adult inanga in the Waiwhetu Stream had deeper bodies than inanga in both the Wainuiomata River and the Hutt River. Inanga collected from the Hutt and Wainuiomata rivers displayed similar body depths, despite strong differences in mean flow between streams (Fig. 2.3b, Table 2.1). Variation in the body depth of adult inanga may therefore be more closely associated with food supply than flow rate. Adult inanga are primarily drift feeders, maintaining a steady position in the water column and collecting small invertebrates that are carried downstream (McDowall, 1968; Jowett, 2002). Inanga tend to position themselves in areas of the stream that maximise the delivery of food while minimising the energetic costs of swimming (Jowett, 2002). The Waiwhetu Stream may have provided optimal drift feeding habitats for adult development, with both low water flow and high concentrations of food. The Hutt River is a rocky bedded system with strong current, and likely has less available feeding habitats for adult inanga than the Waiwhetu Stream. Low concentrations of food can result in stunted growth and a shallower body shape in larval inanga (Barriga et al., 2012), and may have similar implications for adult stages. Determining the relative influence of food supply and flow rate on body shape, however, was beyond the scope of this study, and could be investigated using a controlled laboratory experiment.

Pre-spawning stages of adult inanga had deeper heads in the Waiwhetu Stream, intermediate head depths in the Wainuiomata River, and shallower heads in the Hutt River. Variation in head morphology among freshwater fish has been attributed to differences in predation intensity (Milano et al., 2010) and flow rate (Kovac, 2006). Intraspecific comparisons of freshwater fish living under variable flow suggest a general trend towards a shallower head depth in high flow systems (Langerhans \& Reznick, 2010). The Hutt River has greater mean flow 
and is more dynamic and prone to flooding than either the Waiwhetu Stream or the Wainuiomata River. Boundary conditions at river edges however may have provided slower current in the Hutt River compared with the Waiwhetu Stream and Wainuiomata River. The Wainuiomata River has a more consistent, intermediate flow rate and the Waiwhetu Stream has low mean flow and floods occasionally. This study provides some preliminary evidence that variation in inanga head depth may be related to flow regime. Having a shallower head can reduce drag and the energetic costs of movement in larger, high-flow river systems (Langerhans \& Reznick, 2010).

The caudal peduncle depth of pre-spawning stage adult inanga showed relatively low variation among streams when compared with head and body depths. Fish collected from the Hutt River had slightly shallower caudal peduncles than fish collected from other sites. A deeper caudal peduncle and larger caudal fin can improve the propulsive area used to generate thrust, enhancing unsteady swimming performance and allowing for swift acceleration (Langerhans \& Reznick, 2010; Chapman et al., 2015). Individuals with large, deep bodies may experience greater survival in environments with high predator densities (Langerhans \& Reznick, 2010). However, a body shape with a deep posterior and shallow anterior is un-streamlined, and can increase drag when swimming steadily in a straight line (Langerhans \& Reznick, 2010). Although fish in the Hutt River displayed shallower caudal peduncles, they also displayed shallower body depths. Rather than displaying a streamlined shape, inanga in the Hutt River appeared to have an overall shallower body, suggestive of low food supply rather than a morphological adaption to reduce drag.

\subsection{2 - Potential environmental factors influencing adult development}

Spawning-stage adult inanga collected from the Wainuiomata River were far larger than fish from either the Hutt River or the Waiwhetu Stream. Although food concentrations appear to be higher in the Waiwhetu Stream, density effects may 
have restricted adult growth. High density is correlated with reduced condition and growth of juvenile reef fish (Ford et al., 2016), and may have similarly restricted the growth of inanga in the small and densely populated Waiwhetu Stream. Spawning-stage adult inanga displayed similar fineness ratios in the Hutt River and the Waiwhetu Stream, with the exception of samples collected in May, when fish in the Waiwhetu Stream displayed significantly lower fineness ratios (deeper bodies). This is likely a result of substantial differences in the maturity stage of fish, rather than relatively small morphological differences related to local variation in environmental conditions. Within-stream variation in fineness ratios were greater in the Hutt River compared with the Waiwhetu Stream during March and May. The high variability in fineness ratio during these months suggest fish collected from spawning grounds in the Hutt River were comprised of individuals that were at different stages of maturity. Spawning grounds in the Hutt River may therefore be supplied by inanga from a diverse range of both main stem stream habitats and smaller tributaries further inland.

Intraspecific variation in body shape among populations of freshwater fish is also related with differences in predation intensity (Persson, 1996; Chang, 2005). Both the Hutt River and the Wainuiomata River support valuable brown trout fisheries (Strickland \& Quarterman, 2001; Ausseil \& Hayes, 2013), a known predator of inanga (Milano et al., 2010). The Wainuiomata River in particular is valued as a brown trout river, and trout were observed cruising the riverbank in the vicinity of inanga shoals on all sampling days for pre-spawning stage adults in the Wainuiomata River. Records of freshwater fish scales held by the New Zealand Marine Department indicate the Waiwhetu Stream used to support considerable numbers of brown trout up to the mid 1930's (Eldon, 1967). I neither caught or observed any brown trout during sampling in the summer of 2015 and autumn of 2016. However, two brown trout were spotted in the Waiwhetu Stream during November of 2016 (Merritt, pers. comm.). As brown trout require relatively high water quality (Ausseil \& Hayes, 2013), they likely are not found in high numbers in the Waiwhetu Stream due to the systems current degraded state. 
The larger size of inanga in the Wainuiomata River could be a result of selective predation by brown trout on smaller individuals. Many predatory fish are gape limited, and can only consume prey items of a certain size class (Persson, 1996). However, whitefish up to $14 \mathrm{~cm}$ in length have been recovered from the gut of brown trout (Jensen et al., 2004), and inanga typically mature at approximately 7.4 - 9.1cm standard length (McDowall, 1968). Brown trout are therefore unlikely to have been gape limited in their predation on inanga. Predators can influence the body shape of prey as well as their size. Prey species in environments with high predator densities often display deeper bodies with a large posterior and propulsive area (Langerhans \& Reznick, 2010). A deeper body shape with high posterior surface area and a shallow head region can enhance acceleration and burst swimming performance allowing for greater evasion of predatory strikes (Langerhans \& Reznick, 2010). While a deep posterior can improve burst swimming performance and predator evasion, this shape can also increase drag when moving forward in a straight line (Langerhans \& Reznick, 2010). Inanga may therefore undergo an ecological tradeoff in body shape, with a deeper body shape improving survival in environments with high predator densities, and a shallower body shape reducing drag and the energetic costs of drift feeding in high flow environments. Variation in food concentrations among streams, however, may have confounded these patterns in the present study. Further exploratory field studies could attempt to quantify these relationships by comparing the morphology of adult inanga populations in rivers with similar food concentrations and substantial differences in either flow rate or predation intensity.

\subsection{3 - Conclusions}

Inanga showed significant variation in body shape between streams, with small morphological differences between pre-spawning stage populations and greater variation both within and between streams during the spawning season. Prespawning stage inanga had deeper bodies in the Waiwhetu Stream, with no significant difference detected between the Wainuiomata River and the Hutt 
River, despite clear differences in flow between streams. Variation in the body depth of adult inanga may therefore be more closely associated with food supply than flow rate. Pre-spawning stage inanga had shallow heads in the Hutt River, deep heads in the Waiwhetu Stream and an intermediate head morphology in the Wainuiomata River. This study provides some preliminary evidence that inanga in high flow environments may develop a shallower head morphology. Further research could focus on isolating the influence of variation in flow rate on inanga morphology, by simulating uni-directional flow conditions in the laboratory while controlling for additional variables (food supply, temperature etc.).

Inanga in the Wainuiomata River displayed slightly larger sizes prior to the spawning season and substantially larger bodies during the spawning season. Although the Waiwhetu Stream may have had a greater supply of food, high densities of fish in smaller stream systems could constrain adult growth. During May, spawning adults displayed significantly deeper bodies in the Waiwhetu Stream compared with the Hutt River, potentially due to substantial differences in maturity. Inanga in the Hutt River also displayed greater within-month variation in morphology, suggesting breeding shoals were comprised of a more heterogeneous group of fish. Spawning grounds in the Hutt River are likely supplied by inanga from a diverse range of both main stem stream habitats and smaller tributaries further inland. Overall, inanga's morphological development appears to be influenced by multiple aspects of the stream environment, with food supply and flow rate proposed as key drivers of variation. Further research could focus on isolating and quantifying the relative influence of these factors on inanga's morphological development. 


\section{Chapter 3 - Changes in reproductive output and energetic reserves of adult inanga (Galaxias maculatus) during the spawning season}

\section{1 - Introduction}

Inanga (Galaxias maculatus) are the major component of New Zealand's whitebait fisheries (McDowall, 1968; Barbee et al., 2011). Most inanga are amphidromous, with an oceanic larval period and a freshwater adult stage (Jung et al., 2009). Monitoring of adult populations in both North and South Island river systems suggest a general decline in numbers of fish, and improved knowledge of the factors that influence reproductive output may contribute to more effective management that could prevent further losses and/or facilitate recovery (Strickland \& Quarterman, 2001; Hickford \& Schiel, 2013). Inanga's reproductive biology has been the focus of considerable research (McDowall, 1968; Stevens et al., 2016), and far more information is available on the freshwater adults than the dispersive marine larvae (McDowall, 1968; Barbee \& Swearer, 2007). However, the behaviour patterns and fates of the freshwater adults outside of the spawning locations and seasons are poorly known, as are the factors that may influence the survival and development of pre-spawning stages of inanga.

During autumn adult inanga migrate downstream in large breeding shoals to spawn near the saltwater wedge (the furthest inland penetration of saltwater at high tide). Although some individuals spawn more than once (Stevens et al., 2016), the majority of fish die after spawning (McDowall, 1968; Hickford \& Schiel, 2013). Reproductive output of a stream is therefore largely dependent on annual recruitment. Thus, annual marine recruits and freshwater development (somatic and reproductive growth) of these recruits is critically important for these 
populations. Adult inanga's reproductive output is known to vary substantially within and among rivers in New Zealand, and this is often assumed to be a function of the quality of stream habitat for the development of inanga prior to spawning, and the availability of lowland spawning habitats (McDowall, 1968). Timing of reproduction also varies between geographic regions, with later onset of the spawning season at northerly latitudes, and earlier development of reproductive tissues on the west coast of the South Island compared with the east coast (Stevens et al., 2016). Spawning habitat surveys by the Ministry of Primary Industries (MPI) and monitoring of inanga's reproductive activity in the Waikanae River suggest a peak in spawning activity from March-June in the North Island (McDowall, 1968; Smith, 2015). Inanga morphology and breeding biology is known to vary between streams with substantial differences in food supply and flow rate (McDowall, 1968; Jowett, 2002). Rivers with a high concentration of food may improve foraging efficiency (Jowett, 2002), and result in greater storage of energetic reserves prior to the spawning season (Shulman \& Love, 1999; Dominguez-Petit \& Saborido-Rey, 2010).

Energy not immediately required for an animal to function can be stored and used during later life stages, representing a tradeoff between somatic and reproductive growth (Varpe et al., 2009). Many animals in cold environments store energy as fatty-acid lipids in fat and blubber reserves, providing both thermal insulation and readily available resources during periods of low food supply (Prestrud, 1991; Varpe et al., 2009; Sainmont et al., 2014). Freshwater fish often store surplus energy in the liver and somatic tissues, to be utilised during periods of low food availability (Heermann et al., 2009; Dominguez-Petit \& Saborido-Rey, 2010). Wild populations of stream fish in temperate systems typically undergo seasonal changes in energetic reserves, with some species amassing considerable energy stores prior to the spawning season and others relying on high food availability during the breeding period (Dominguez-Petit \& Saborido-Rey, 2010). Many freshwater fish display an inverse relationship between the weight of the liver and reproductive tissues, with energy stored in 
the liver gradually used as populations approach spawning (Shulman \& Love, 1999; Dominguez-Petit \& Saborido-Rey, 2010). Adult inanga populations that can stockpile greater energetic reserves prior to the spawning season may be capable of higher reproductive output during peak breeding periods.

Here, I examine variability in the reproductive output and energetic reserves of adult inanga during the spawning season. Potential environmental drivers of variation in reproductive output and energetic reserves are discussed. I hypothesised that adult populations with greater energetic reserves early in the spawning season would display greater reproductive output during the peak of the spawning season. Due to the deeper bodies of adult inanga observed in the Waiwhetu Stream (chapter 2, Fig. 2.3b), I expected inanga in the Waiwhetu Stream to have greater energetic reserves and higher reproductive output during the spawning season compared with the Hutt River. Specifically, in this chapter I address the following question:

How does inanga reproductive output and energetic reserves vary over the spawning season within and between the Hutt River and Waiwhetu Stream?

\section{2 - Methods}

\subsection{1 - Study system and field sampling}

Inanga were collected on monthly intervals from March-June 2016 at lowland spawning grounds to measure variability in reproductive output and energetic reserves. For a full description of study system and location of study sites see Figure 2.1 and Table 2.1 in chapter 2. Spawning adults were successfully collected in each month from the Hutt River and the Waiwhetu Stream. A sample of adult inanga was collected from the Wainuiomata River in March, however no further fish were caught or observed in the river from April-June. Therefore, I limit my evaluation of temporal patterns to the Hutt River and the Waiwhetu Stream 
(I do not consider data from the Wainuiomata River in this chapter). For all collections, I used two southland sock nets (large fyke nets with mouth opening $1.3 \mathrm{~m} \times 1.02 \mathrm{~m}$, length $3.5 \mathrm{~m})$. Nets were set on the upstream side of spawning grounds to target fish migrating downstream to spawn. Nets were deployed within $2 \mathrm{~m}$ of the riverbank and spaced approximately $20 \mathrm{~m}$ apart, and were checked on half-hour or hourly intervals for approximately 6 hours (or until I obtained a sample size of $\sim 20$ fish). Due to lower than expected catch rates at spawning habitat in the Hutt River near the Sladden Park boat ramp a smaller sock net (mouth opening $1.1 \mathrm{~m} \times 0.710 \mathrm{~m}$, length $2 \mathrm{~m}$ ) was also set in the Hutt River main stem approximately $200 \mathrm{~m}$ northeast of the boat ramp.

\subsection{2 - Quantifying reproductive output and energetic reserves}

A subsample of spawning adult inanga caught from March-June 2016 were transferred to plastic containers filled with river water and returned to the laboratory to enable me to estimate reproductive output and energetic reserves (my sampling was restricted to a maximum of 50 individuals per river, following Department of Conservation permit 48312-RES). I laterally photographed fish using the same aquarium described in chapter 2. Fish were then euthanized in an ice water/ethanol slurry and standard length and maximum body depth measured using a set of manual calipers. I recorded the wet weight of each adult to $0.01 \mathrm{~g}$ using an analytical balance.

Spawning adults were dissected with a single cut along the stomach from the ventral base of the head to the posterior edge of the urogenital pore. I extracted the entire gonad (both ovaries and all loose eggs for females, both testes and any freely expressed milt for males) and recorded gonad wet weight to $0.01 \mathrm{~g}$. Individual reproductive output can be estimated from the weight of internal reproductive tissues in spawning fish, the weight of egg clutches deposited in the external environment, or by egg counts (McDowall \& Croom, 1988; Legendre 
et al., 1992). I used gonad wet weight to estimate individual reproductive output. I removed the liver and recorded liver wet weight to $0.01 \mathrm{~g}$. I then recorded eviscerated wet weight, and preserved the gonads and carcass in $98 \%$ ethanol. Due to difficulties in obtaining sufficient sample sizes in most months, male and females were not analysed separately. Potential implications of this approach are outlined in the limitations section of chapter 4 .

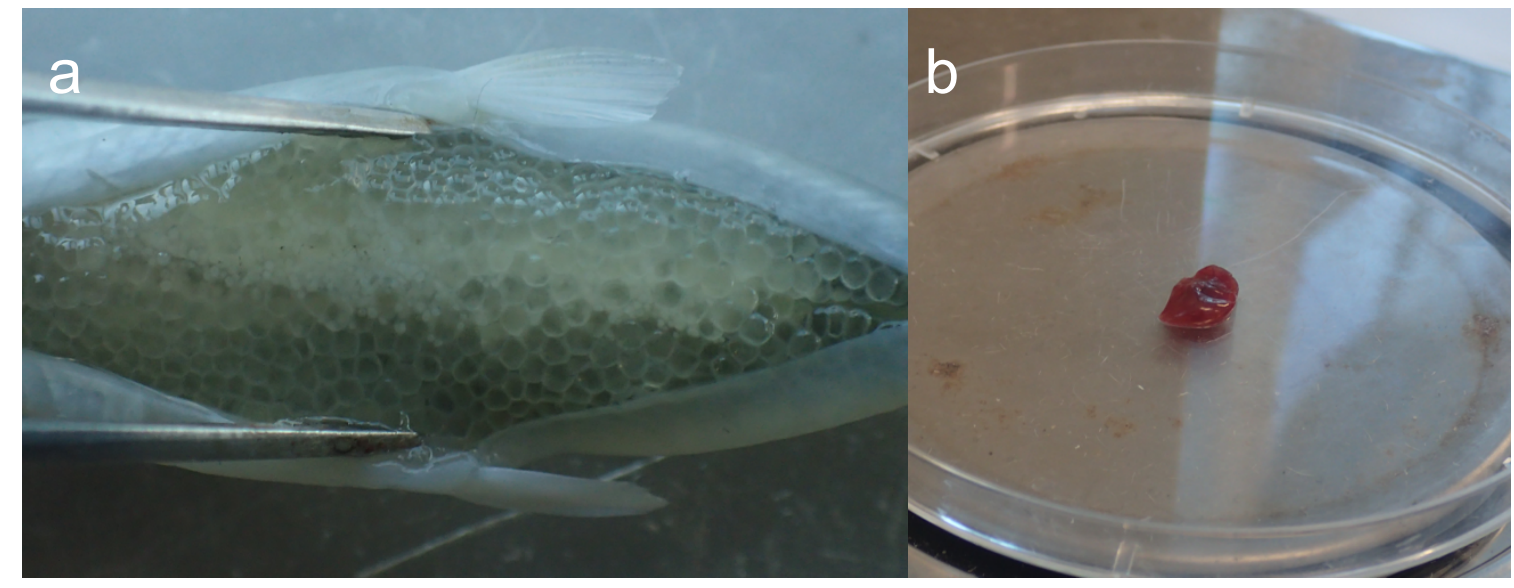

Figure 3.1 - (a) Female adult inanga showing egg mass before removal and weighing, and (b) inanga liver on balance scales.

I estimated reproductive output using gonad weight. I estimated maturity with the gonadosomatic index (GSI). GSI is the percent of the total body weight comprised of the gonad, and is used to estimate changes in maturity during reproductive periods (Zeyl et al., 2013).

Gonadosomatic index $=$ gonad weight $/$ total fish weight $\times 100$

I estimated energetic reserves using the hepatosomatic index ( $\mathrm{HSI})$. $\mathrm{HSI}$ is the percent of the total body weight comprised of the liver, and is used to estimate available energetic reserves (Dominguez-Petit \& Saborido-Rey, 2010).

Hepatosomatic index $=$ liver weight $/$ total fish weight $\times 100$ 
$\mathrm{HSI}$ is typically used to estimate changes in energetic reserves in response to changes in maturity (Cek et al., 2001), or to detect a physiological response to pollution events (Al-Ghais, 2013). Some freshwater fish display higher HSI values at pollution-impacted sites compared with control sites (Sindhe \& Kulkarni, 2004; Al-Ghais, 2013). Liver wet weights were not recorded during March, therefore data on $\mathrm{HSI}$ is only available from April-June. Many freshwater fish show an inverse relationship between GSI and HSI during the spawning season (as fish invest more heavily in reproductive tissues they utilise energetic reserves stored in the liver).

\subsection{4 - Spatio-temporal variability in reproductive output and energetic reserves}

I evaluated spatio-temporal variation in reproductive output and energetic reserves during inanga's spawning season in the Hutt River and the Waiwhetu Stream. Specifically, I used gonad weight to measure reproductive output, the hepatosomatic index to measure energetic reserves, and the gonadosomatic index to measure changes in maturity. I evaluated assumptions of normality and homogeneity of variance using residuals vs fitted and quantile-quantile ( $Q-Q)$ plots. I used three two-way ANOVAs to test for significant differences in gonad weight, GSI and HSI between months (March-June) and stream (Hutt River and Waiwhetu Stream). Post hoc Tukey tests were used to test for significant differences between streams and within months (i.e. gonad weights during May compared between the Hutt River and the Waiwhetu Stream). Data was analysed in $\mathrm{R}$ Studio Version 0.99 .484 using the $\mathrm{R}$ package stats 3.3.1. The ggplot2 package was used for plotting and presentation of results. 


\section{4 - Results}

Standard length of spawning adult inanga ranged from $4.716-8.903 \mathrm{~cm}$. A total of 37 spawning adults were collected from the Hutt River $(n=5$ in March, $n=7$ in April, $n=12$ in May, $n=13$ in June). A total of 50 spawning adults were collected from the Waiwhetu Stream ( $n=20$ in March, $n=10$ in April, $n=10$ in May, $\mathrm{n}=10$ in June).

\subsection{1 - Spatio-temporal variability in reproductive output and energetic reserves}

Gonad weights of sampled inanga did not vary between streams (Fig. 3.2a: $F_{1,79}$ $=0.1312, p=0.7181$ ). Gonad weights of inanga did vary across months (Fig. 3.2a: $\left.F_{3,79}=6.6655, p=0.0005\right)$. There was no significant interaction of stream and sampling month on gonad weight (Fig. 3.2a: $F_{3,79}=1.8161, p=0.1510$ ). Post hoc Tukey tests for fish collected in March indicate higher gonad weights in the Hutt River $(p<0.0001)$. Fish collected during May had higher gonad weights in the Waiwhetu Stream compared with the Hutt River $(p=0.0005)$. Tukey tests indicated no significant difference in gonad weight between streams in April ( $p=$ $0.9891)$ and June $(p=0.9987)$.

GSI of sampled inanga did not vary between streams (Fig. 3.2b: $F_{1,79}=1.3979$, $p=0.2406$ ). GSI of inanga did vary across months (Fig. 3.2a: $F_{3,79}=7.0645, p$ $=0.0002$ ). However, there was a significant interaction of stream and month on GSI (Fig. 3.2b: $F_{3,79}=8.2519, p<0.0001$ ), indicating that differences in GSI between streams depended on sampling month. Post hoc Tukey tests for collections made in March indicate higher GSI in the Hutt River $(p<0.0001)$. Inanga had greater GSI in the Waiwhetu Stream compared with the Hutt River in May $(p=0.0014)$ and June $(p<0.0001)$. No significant difference in GSI between the Hutt River and the Waiwhetu Stream during April ( $p=0.1612$ ). 
$\mathrm{HSI}$ of sampled inanga did not vary between streams (Fig. 3.2c: $F_{1,56}=0.6753$, $p=0.4147$ ). $\mathrm{HSI}$ of inanga did vary across months (Fig. 3.2c: $F_{2,56}=3.8538, p$ $=0.02704)$. However, there was a significant interaction of stream and month on HSI (Fig. 3.2c: $F_{2,56}=3.4123, p<0.0399$ ) indicating that differences in HSI between streams depended on sampling month. Post hoc Tukey tests indicated greater $\mathrm{HSI}$ in the Waiwhetu Stream during April $(p<0.0001)$. Tukey tests indicated no significant difference in HSI between streams during May ( $p=$ $0.4595)$ and June $(p=0.9416)$. 

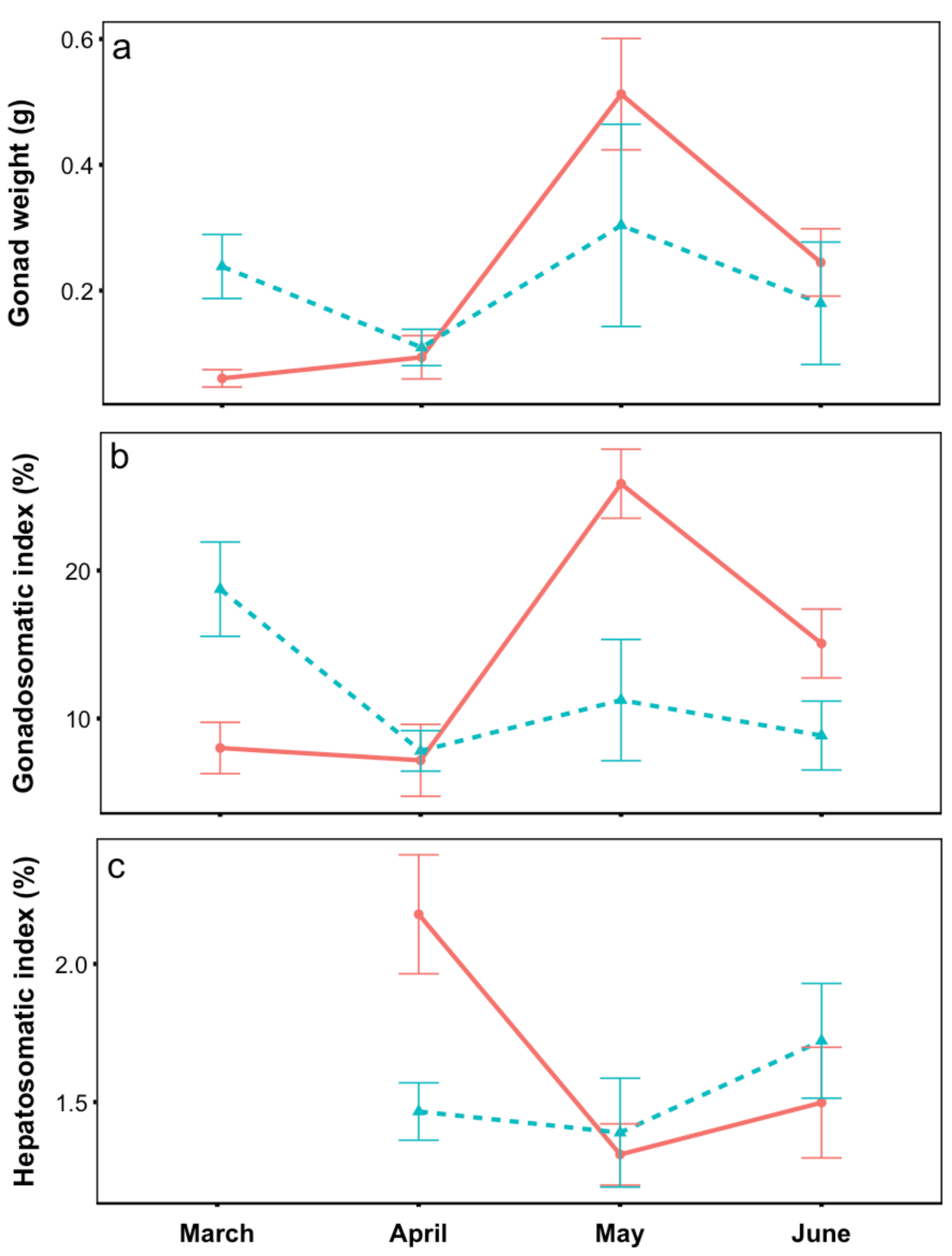

Figure 3.2 - Spawning adult inanga (a) gonad weight, (b) gonadosomatic index (\% of total body weight comprised of gonad), and (c) hepatosomatic index (\% of total body weight comprised of liver). Waiwhetu Stream (solid red line with circles) and Hutt River (dashed blue line with triangles). Given are mean values for each month and average \pm SE (error bars). The hepatosomatic index was not calculated for March as liver weights were only recorded from April through June. 


\section{5 - Discussion}

\subsection{1 - Variability in reproductive output and energetic reserves}

Inanga in the Waiwhetu Stream had high energetic reserves in April followed by low energetic reserves and high reproductive output in May (Fig. 3.1a and Fig. 3.1c). Inanga in the Hutt River displayed low energetic reserves in April followed by low energetic reserves and a slight increase in reproductive output during May (Fig. 3.1a and Fig. 3.1c). Many freshwater fish use energy stored in the liver and somatic tissues for the production of reproductive tissues (Shulman \& Love, 1999; Dominguez-Petit \& Saborido-Rey, 2010). The greater energetic reserves shown by inanga during April in the Waiwhetu Stream compared with the Hutt River may have facilitated higher production of reproductive tissues and greater reproductive output during May.

Reproductive activity peaked during May in the Waiwhetu Stream, with greater gonad weights and GSI values compared with other sampling months. Both GSI and gonad weight in the Waiwhetu Stream declined after the peak in May. Reproductive activity displayed two peaks in the Hutt River during March and May. Gonad weights in the Hutt River were slightly higher in May compared with March although no significant difference was detected, potentially due to high variability in gonad weight during May. The high variability in gonad weight during May in the Hutt River suggests breeding shoals may have been comprised of individuals at different stages of maturity. Inanga collected from spawning grounds in the Hutt River may have been supplied by breeding shoals from a diverse range of main stem habitats and smaller tributaries further inland. Spawning habitats in large complex river systems such as the Hutt River may therefore be supplied by fish on different spawning schedules, affording diversity in spawning and perhaps greater survival of dispersive larvae.

Gonad weight and GSI were strongly correlated in the Waiwhetu Stream, however the association was not as strong in the Hutt River. Relatively high 
gonad weights in the Hutt River during May were accompanied by low GSI values. It is possible that adult inanga collected during May in the Hutt River were larger and less mature than inanga in the Waiwhetu Stream (i.e. although gonads in the Hutt River were large compared with those in the Waiwhetu Stream they were relatively small compared with individual body weight).

\subsection{2 - Potential environmental factors that influence reproductive output}

The Waiwhetu Stream may provide a more productive environment for inanga, with both high food concentrations and low water flow allowing inanga to amass greater energy stores during the months leading up to the spawning season. Stored energy could then be invested in reproductive tissues, resulting in the high gonad weights and GSI values recorded during May in the Waiwhetu Stream. In the Hutt River HSI scores were significantly lower during April, indicating that inanga had less available energetic reserves than fish in the Waiwhetu Stream. Lower energetic reserves in the Hutt River during April were potentially a result of low food availability, and may explain the lower reproductive output in subsequent months compared with the Waiwhetu Stream (i.e. inanga in the Hutt River did not have sufficient energy stored in the liver to produce reproductive tissues to the same degree as fish in the Waiwhetu Stream).

Variation in water quality can also influence the development of freshwater fish (Sindhe \& Kulkarni, 2004), and may have contributed to differences in reproduction and morphology among streams. The Waiwhetu Stream is a polluted system, with low water quality in the lower reaches of the stream that pass through the residential and industrial areas of Gracefield in Lower Hutt (Perrie et al., 2012). Despite the degraded state of the Waiwhetu Stream, inanga had greater reproductive output and were found in higher densities than fish in the Hutt River. Previous freshwater fish surveys of the Waiwhetu Stream also indicate high numbers of inanga despite the low water quality of the stream (Strickland \& Quarterman, 2001; Perrie et al., 2012). Inanga display considerable resilience to water pollution, and have greater tolerance of low $\mathrm{pH}$ 
waters than many other native galaxiids (Jellyman \& Harding, 2014). Eutrophication of stream systems due to run-off from nearby terrestrial environments can enhance the concentration of nutrients suspended in the water column and increase the growth of aquatic plants (Mesters, 1990; Dunck et al., 2015). The Waiwhetu Stream may therefore constitute a valuable system for adult inanga by providing habitat with high food concentrations and low flow rates.

Although large livers in the Waiwhetu Stream likely indicate greater energetic reserves, a larger liver could be an adaption to cope with low water quality. The liver is used for detoxification in many animals (Sindhe \& Kulkarni, 2004), and larger livers in the polluted Waiwhetu Stream may be an adaptive response to improve cycling of pollutants through the body and reduce accumulation of harmful substances in somatic tissues. However, inanga are relatively tolerant of pollution and are found in degraded freshwater streams throughout New Zealand (Jellyman \& Harding, 2014). Furthermore, inanga only inhabit freshwater for $\sim 4-6$ months before spawning, and it is unlikely that inanga were able to undergo such significant changes in liver morphology over such a short time period. In addition, inanga in the Waiwhetu Stream displayed greater gonad weights and GSI scores than the Hutt River, suggesting that inanga's reproductive output was not negatively affected by the current level of water quality in the Waiwhetu Stream. Therefore, large livers in the Waiwhetu Stream suggest greater energetic reserves and may reflect a greater supply of food in the Waiwhetu Stream for developing adult inanga.

\subsection{3 - Spawning patterns in regards to river size and complexity}

McDowall (1968) compared the morphology and reproductive output of spawning adult populations from the Waikanae River and the Makara Stream in the North Island, and Ship Creek on the west coast of the South Island. The Waikanae River is a large, fast-flowing braided river system, with little suitable habitat for developing inanga. The Makara Stream is of intermediate size and flow, with 
abundant aquatic vegetation and numerous slow flowing pool habitats that are favored by inanga (Jowett, 2002). Ship Creek is the smallest of the three streams, and is a nutrient enriched system that drains lowland bush swamp in the Haast region of the South Island's west coast. Spawning female inanga had lower fecundities and smaller body sizes in the Waikanae River, intermediate in the Makara Stream and large bodies with high fecundities in Ship Creek (McDowall, 1968).

Small, forested streams such as Ship Creek potentially provide ideal habitats for pre-spawning stage inanga, with both input of nutrients to the stream from surrounding vegetation, abundant invertebrates and high availability of the lowflow pool habitats preferred by adult shoals (Jowett, 2002). Larger river systems such as the Waikanae River likely do not provide ideal stream habitats for developing inanga, due to both low food availability and greater energetic demands of movement in a high flow environment. The reproductive output among spawning adult populations may be influenced by the quality of stream habitats for developing inanga pre-spawning season. Inanga in smaller streams with high food supply may develop deeper bodies with larger body cavities and have more energy reserves available to invest in reproductive tissues during the spawning season. Spawning inanga with a shallower body shape may have restricted reproductive output during the breeding season.

Although smaller, slow flowing streams appear to provide productive environments for adult development and may enhance reproductive output (McDowall 1968), fish collected from the small Waiwhetu Stream in the present study also appeared to be comprised of a more homogenous cohort of fish. Furthermore, fish only displayed one peak in reproductive output in May in the Waiwhetu Stream, whereas there were two smaller peaks in March and May in the Hutt River. Smaller stream systems (e.g. the Waiwhetu Stream) may display greater reproductive output, however spawning activity may be concentrated over a shorter time period. In larger river systems such as the Hutt River (where 
spawning grounds are potentially supplied by a diverse range of both main stem habitats and smaller tributaries inland) reproductive output may not be as high as in smaller, slow flowing streams, however the supply of fish from a diverse range of habitats and phenotypes may provide some resilience to disturbance events that could disrupt spawning (i.e. stock trampling/removal of riparian vegetation from key spawning areas during the spawning period). I suggest that larger rivers, such as the Hutt River, may be of disproportional importance to replenishment of inanga stocks, despite the apparently lower reproductive output when compared with smaller stream systems such as the Waiwhetu Stream.

\subsection{4 - Conclusions}

Inanga attained greater maximum gonad weights and GSI values in the Waiwhetu Stream compared with the Hutt River, indicating higher reproductive output in the Waiwhetu Stream. Inanga also had larger livers in the Waiwhetu Stream during April when compared with the Hutt River, indicating grater energetic reserves. Inanga in the Hutt River may not have had the required energetic reserves to produce sufficient reproductive tissues. The Waiwhetu Stream is a polluted system, however in its current state the stream has abundant aquatic vegetation and may have a greater supply of invertebrates for inanga to consume. In the Hutt River suitable feeding habitats and available resources may be few and far between, with the additional energetic costs of movement in a high flow environment further restricting energetic storage and the production of reproductive tissues. Although inanga appeared to have lower reproductive output in the Hutt River, fish displayed two peaks in reproductive output during March and May. A more concentrated breeding season in smaller systems such as the Waiwhetu Stream may increase vulnerability to disturbance events (i.e. stock trampling on spawning grounds). Larger, more complex river systems may be more resilient to disturbance during the spawning season, due to greater diversity in the phenotypes and spawning schedules of breeding shoals supplied from both main stem habitats and smaller tributaries further inland. 


\section{Chapter 4 - General discussion}

\section{1 - Summary of findings}

This thesis has described spatio-temporal patterns in the morphology, reproductive output and energetic reserves of adult inanga (Galaxias maculatus), and discussed environmental factors that may have shaped patterns. Prespawning stage adult inanga in the Waiwhetu Stream displayed significantly deeper bodies than fish in either the Wainuiomata or Hutt rivers, potentially due to greater food concentrations and/or lower flow rates. No significant difference in inanga body depth was detected between the Wainuiomata River and the Hutt River, despite substantial differences in flow. Variation in inanga body depth may therefore be more highly correlated with food supply than flow rate. Prespawning stage inanga displayed shallow heads in the Hutt River, an intermediate head morphology in the Wainuiomata River, and deep heads in the Waiwhetu Stream. This study provides some preliminary evidence that variation in inanga head depth may be related to flow regime. A shallower head morphology could reduce drag and the energetic costs of movement in higher flow river systems.

Spawning-stage adult inanga displayed greater variation in body shape both within and between streams compared with pre-spawning stage populations, potentially due to high variability in maturity within sampling months. Morphological variation within sampling months was higher in the Hutt River compared with the Waiwhetu Stream, suggesting lowland spawning grounds in the Hutt River may be supplied by breeding shoals from both main stem habitats and smaller tributaries further inland. Measurements of gonad weight and the gonadosomatic index in the Waiwhetu Stream suggest a peak in reproductive 
activity during May, with two peaks during March and May in the Hutt River. Overall, spawning adults displayed greater reproductive output in the Waiwhetu Stream compared with the Hutt River, suggesting the Waiwhetu Stream is a productive system for inanga despite the streams relatively low water quality. Furthermore, inanga in the Waiwhetu Stream displayed significantly heavier livers in April compared with the Hutt River, suggesting fish were able to stockpile greater energetic reserves prior to the peak in the spawning season during May. Inanga that are able to stockpile greater energetic reserves during pre-spawn adult stages may have greater reproductive output during spawning adult stages. Inanga may be capable of thriving in the Waiwhetu Stream by exploiting the elevated supply of food caused by nutrient input from nearby terrestrial sources.

Although reproductive output was greater in the Waiwhetu Stream, spawning adult inanga also displayed less within-month phenotypic variation. Smaller systems such as the Waiwhetu Stream may be comprised of a more homogenous population of fish, and although reproductive output of the system may be greater, spawning activity may be concentrated over a shorter time period. Smaller streams may therefore be more vulnerable to disturbance events (i.e. stock trampling of spawning grounds) that could severely damage overall reproductive output. Spawning grounds in larger, more complex river systems such as the Hutt River may be supplied from a diverse range of main stem habitats and smaller tributaries further inland. I hypothesise that spawning grounds in larger river systems such as the Hutt River may be more resilient to disturbance events, because these systems may enable multiple opportunities for spawning due to a greater diversity in habitats and phenotypes.

\section{2 - Management of pre-spawning stage adult inanga populations}

Freshwater adult populations are primarily threatened by degradation of lowland spawning habitats, predation by introduced trout and obstructions to fish passage during inland migrations (McDowall, 1968). Adult populations in several 
important whitebaiting rivers in both the North and South Island are in decline, and are an object of concern for some regional councils (Strickland \& Quarterman, 2001; Hickford \& Schiel, 2013). There are thus clear incentives to maintain and increase adult populations in New Zealand. Management of inanga populations in New Zealand is currently focused on the restoration of lowland spawning grounds, work that has provided considerable benefits for the reproductive output of stream populations (Hickford \& Schiel, 2013). Management of spawning habitat primarily consists of planting native vegetation used by spawning adults to deposit eggs, stabilising and reinforcing the riverbank and putting up fencing to exclude livestock.

The results reported in this thesis suggest that consideration should be given to implementing several of the restoration techniques used at spawning grounds to improve the quality of stream habitats used by pre-spawn populations. Developing adult inanga primarily inhabit relatively deep, slow moving pool habitats, collecting food items carried downstream by the river (Jowett, 2002). By identifying exposed sections of the river with low cover of vegetation, slow current and deep pools, and then planting vegetation and excluding livestock from the river's edge, the quality of stream habitats for adult populations prior to the spawning season could be improved. Higher quality inland stream habitats may enhance the growth of inanga prior to the spawning season, potentially resulting in a supply of larger and deeper-bodied spawning adults to lowland breeding grounds. A deep-bodied morphology is known to enhance the reproductive output of many stream fish (Legendre et al., 1992; Crossin et al., 2004), and may also provide significant reproductive benefits for spawning adult inanga. Combined management of lowland breeding grounds used by spawning adults and inland stream habitats used by pre-spawn inanga may increase the reproductive output of adult inanga populations. Larger adult populations could 
increase the number of juvenile fish returning to stream habitats in subsequent years, and improve the resilience of whitebait stocks to harvest.

\section{3 - Future directions and limitations of the present study}

The main limitation of the present study concerns determining the mechanisms that actually drive patterns of phenotypic variation within and among streams. This thesis suggests that greater body depths in the Waiwhetu Stream may be a result of higher food supply, whereas variation in head depth may be more highly correlated with flow regime. However, given the field research setting the relative influence of these factors on body shape could not be determined. Exploratory field research in conjunction with controlled laboratory studies may allow researchers to isolate and quantify the relative influence of key environmental variables on inanga's morphological development. Specifically, the effects of between-stream variability in food supply, flow rate and predation intensity are proposed as critical factors influencing inanga morphological development and reproductive biology.

A second limitation of the present study concerns determining whether the spawning adults sampled at lowland breeding grounds were supplied from habitats in the main stem of the river or from smaller tributaries further inland. As fish entered the spawning season variation in body shape both within and between streams increased, potentially due to variability in the maturity of fish within sampling months. Within-stream variation was higher in the larger Hutt River compared with the Waiwhetu Stream, suggesting lowland breeding grounds in the Hutt River may be supplied by breeding shoals from a more diverse range of main stem habitats and smaller tributaries further inland. Spawning adults collected from lowland sites during the breeding season may therefore be supplied from smaller tributaries off the main stem in large, more complex river systems. In the Waiwhetu Stream this is not likely to be an issue, as the stream is small and has no tributaries that separate from the main stem (Perrie et al., 2012). In the Wainuiomata River there is one small tributary called 
Catchpool Stream that is within the range of inanga's inland distribution and may have supplied adult fish to spawning grounds near the rivermouth (Strickland \& Quarterman, 2001). The supply of spawning adults from stream habitats outside the main stem of the river is more likely to be an issue in the Hutt River, which is the largest of the three systems and has several smaller tributaries. The combined analysis of males in and females due to low sample sizes may have also provided difficulties for analysis, as high variability in sex ratios and substantial differences in body shape and size between sexes may have confounded results. In particular, estimates of reproductive output and maturity likely varied between sexes, and future research should attempt to sample sufficient numbers of both males and females and analyse sexes separately.

To determine the source of breeding shoals migrating downstream to spawning grounds would require a tagging study, a procedure that was not deemed feasible in the present study due to the high number of tags required and substantial cost involved. Tagging of freshwater fish often involves fin clipping, where a small section of the fin is removed in a specific place that will allow reidentification when individuals are recaptured. Inanga primarily swim using the caudal fin / posterior section of the body with minimal use of the pectoral fins for locomotion, therefore fin clipping of the pectoral fins may be a viable option for tagging of adult inanga. Fin clips taken from the caudal fin would potentially influence swimming ability and individual fitness, and could confound the results of a tagging study. However, the surface of inanga's body is coated in a mucous that protects fish from infections in the stream environment. Fin clipping and the handling of fish during clipping may remove this protective coating and expose fish to lethal or non-lethal infections, confounding the results of a tagging study.

A more viable option for tagging and tracking the movement of adult inanga is the use of small elastomer tags. Elastomer tags have been successfully used in the tagging of other small galaxiid fish species (Hansen \& Closs, 2005), and have been trialed with some success on inanga populations in the Manawatu (Mike Joy, pers. corr.). A small dot of colored elastomer is inserted just below 
the skin, with different combinations of color / elastomer position used to differentiate between groups of tagged fish (Hohn \& Petrie-Hanson, 2013). Elastomer tags are a preferred method in the tagging of small fish species (Shima et al., 2012; Hohn \& Petrie-Hanson, 2013), and do not appear to significantly influence the survival of stream fish (Hohn \& Petrie-Hanson, 2013). Elastomer tags potentially have less impact on swimming ability compared with larger tags and may minimise the chance of infection by creating a smaller section of exposed tissue compared with fin clipping. Handling of inanga during elastomer tagging, however, can remove the protective mucous, and researchers should minimise handling time and insert elastomer tags while fish are submerged in water. By tagging stream populations in both the main stem of the Hutt River and smaller tributaries further inland we may be able to measure the relative importance of different sections of the river for the overall reproductive output of the stream. Stream habitats that supply high numbers of large, deep bodied spawning adults to lowland breeding grounds could then be prioritised for management. Specifically, the exclusion of predatory trout and planting of overhanging vegetation in stream habitat preferred by drift feeding adult inanga pre-spawning season may enhance the reproductive output of spawning adult populations and help to protect the species from further decline. 


\section{Bibliography}

Al-Ghais, S. M. (2013). Acetylcholinesterase, glutathione and hepatosomatic index as potential biomarkers of sewage pollution and depuration in fish. Marine Pollution Bulletin, 74(1), 183-186. doi:10.1016/j.marpolbul.2013.07.005

Allibone, R. (2003). Egg cannibalism by inanga (Galaxias maculatus). New Zealand Journal of Marine and Freshwater Research, 37(4), 763-765.

Araki, H. C., B. Blouin, M. S. (2009). Carry-over effect of captive breeding reduces reproductive fitness of wild-born descendants in the wild. Biology Letters, 5(5), 621-624. doi:10.1098/rsbl.2009.0315

Ausseil, O., \& Hayes, J. (2013). Recommended biological and water quality limits for trout fishery and trout spawning waters in the Wellington Region. Cawthron Institute, Greater Wellington Regional Council, 1-58.

Baker, C. F. (2006). Predation of inanga (Galaxias maculatus) eggs by field mice (Mus musculus). Journal of the Royal Society of New Zealand, 36(4), 143-147.

Barbee, N. C., Hale, R., Morrongiello, J., Hicks, A., Semmens, D., Downes, B. J., \& Swearer, S. E. (2011). Large-scale variation in life history traits of the widespread diadromous fish, Galaxias maculatus, reflects geographic differences in local environmental conditions. Marine and Freshwater Research, 62(7), 790-800. doi:10.1071/Mf10284

Barbee, N. C., \& Swearer, S. E. (2007). Characterizing natal source population signatures in the diadromous fish Galaxias maculatus, using embryonic otolith chemistry. Marine Ecology Progress Series, 343, 273-282. doi:10.3354/meps068886

Barriga, J. P., Battini, M. A., Garcia-Asorey, M., Carrea, C., Macchi, P. J., \& Cussac, V. E. (2012). Intraspecific variation in diet, growth, and morphology of landlocked Galaxias maculatus during its larval period: the role of food availability and predation risk. Hydrobiologia, 679(1), 27-41.

doi:10.1007/s10750-011-0849-3 
Barriga, J. P., Battini, M. A., Macchi, P. J., Milano, D., \& Cussac, V. E. (2002). Spatial and temporal distribution of landlocked Galaxias maculatus and Galaxias platei (Pisces : Galaxiidae) in a lake in the South American Andes. New Zealand Journal of Marine and Freshwater Research, 36(2), 345-359.

Bernatchez, L., \& Dodson, J. J. (1987). Relationship between Bioenergetics and Behavior in Anadromous Fish Migrations. Canadian Journal of Fisheries and Aquatic Sciences, 44(2), 399-407. doi:DOI 10.1139/f87-049

Berra, T. M., Crowley, L. E. L. M., Ivantsoff, W., \& Fuerst, P. (1997). Galaxias maculatus: An explanation of its biogeography (vol 47, pg 847, 1996). Marine and Freshwater Research, 48(1), 89-89.

Blob, R. W., Kawano, S. M., Moody, K. N., Bridges, W. C., Maie, T., Ptacek, M. B., ... Schoenfuss, H. L. (2010). Morphological selection and the evaluation of potential tradeoffs between escape from predators and the climbing of waterfalls in the Hawaiian stream goby Sicyopterus stimpsoni. Integr Comp Biol, 50(6), 1185-1199. doi:10.1093/icb/icq070

Carrea, C., Barriga, J. P., Cussac, V. E., \& Ruzzante, D. E. (2012). Genetic and phenotypic differentiation among Galaxias maculatus populations in a Patagonian postglacial lake system. Biological Journal of the Linnean Society, 107(2), 368-382. doi:10.1111/j.1095-8312.2012.01939.x

Cek, S., Bromage, N., Randall, C., \& Rana, K. (2001). Oogenesis, Hepatosomatic and Gonadosomatic Indexes, and Sex Ratio in Rosy Bard (Puntius conchonius). Turkish Journal of Fisheries and Aquatic Sciences, 1, 33-41.

Chang, K. H., Hanazato, T. (2005). Impact of selective predation by Mesocyclops pehpeiensis on a zooplankton community: experimental analysis using mesocosms. Ecological Research, 20(6), 726-732. doi:10.1007/s11284-0050089-y

Chapman, B. B., Hulthen, K., Bronmark, C., Nilsson, P. A., Skov, C., Hansson, L. A., \& Brodersen, J. (2015). Shape up or ship out: migratory behaviour predicts morphology across spatial scale in a freshwater fish. Journal of Animal Ecology, 84(5), 1187-1193. doi:10.1111/1365-2656.12374

Crossin, G. T., Hinch, S. G., Farrell, A. P., Higgs, D. A., Lotto, A. G., Oakes, J. D., \& Healey, M. C. (2004). Energetics and morphology of sockeye salmon: effects 
of upriver migratory distance and elevation. Journal of Fish Biology, 65(3), 788-810. doi:10.1111/j.1095-8649.2004.00486.x

Daverat, F., Limburg, K. E., Thibault, I., Shiao, J. C., Dodson, J. J., Caron, F. O., ... Wickstrom, H. (2006). Phenotypic plasticity of habitat use by three temperate eel species, Anguilla anguilla, A-japonica and A-rostrata. Marine Ecology Progress Series, 308, 231-241. doi:DOI 10.3354/meps308231

Dominguez-Petit, R., \& Saborido-Rey, F. (2010). Changes of proximate composition, energy storage and condition of European hake (Merluccius merluccius, L. 1758) through the spawning season. Fisheries Research, 104, 73-82.

Duffy, C. A. J. (1996). Pre-spawning mortality of koaro (Galaxias brevipinnis) in Apias creek, north-east Ruahine range, North Island, New Zealand. New Zealand Journal of Marine and Freshwater Research, 30(3), 403-405.

Dunck, B., Lima-Fernandes, E., Cassio, F., Cunha, A., Rodrigues, L., \& Pascoal, C. (2015). Responses of primary production, leaf litter decomposition and associated. communities to stream eutrophication. Environmental Pollution, 202, 32-40. doi:10.1016/j.envpol.2015.03.014

Edeline, E. (2007). Adaptive phenotypic plasticity of eel diadromy. Marine Ecology Progress Series, 341, 229-232.

Eldon, G. A. (1967). Freshwater fish scales in the collection of fisheries research division Wellington. New Zealand Marine Department, 1-38.

Ferriz, R. A., Aramburu, W. S., Gomez, S. E., \& Menni, R. C. (2001). Morphological differences in the Galaxias maculatus (Jenyna, 1842) population, an osmeriform fish from southern Argentina. Bioikos, 15(2), 83-89.

Ford, J. R., Shima, J. S., \& Swearer, S. E. (2016). Interactive effects of shelter and conspecific density shape mortality, growth, and condition in juvenile reef fish. Ecology, 97(6), 1373-1380. doi:10.1002/ecy.1436

Graham, D. H. (1956). A Treasury of New Zealand Fishes. 2nd ed. Reed, Wellington, 424. 
Grether, G. F. (2005). Environmental change, phenotypic plasticity, and genetic compensation. American Naturalist, 166(4), E115-123. doi:10.1086/432023

Haas, T. C., Heins, D. C., Blum, M. J. (2015). Predictors of body shape among populations of a stream fish (Cyprinella venusta, Cypriniformes: Cyprinidae). Biological Journal of the Linnean Society, 115(4), 842-858. doi:10.1111/bij.12539

Hansen, E. A., \& Closs, G. P. (2005). Diel activity and home range size in relation to food supply in a drift-feeding stream fish. Behavioural Ecology, 16, 640-648.

Hayes, J. W., Leathwick, J. R., \& Hanchet, S. M. (1989). Fish Distribution Patterns and Their Association with Environmental-Factors in the Mokau River Catchment, New-Zealand. New Zealand Journal of Marine and Freshwater Research, 23(2), 171-180.

Heermann, L., Eriksson, L. O., Magnhagen, C., \& Borcherding, J. (2009). Sizedependent energy storage and winter mortality of perch. Ecology of Freshwater Fish, 18(4), 560-571. doi:10.1111/j.1600-0633.2009.00371.x

Hickford, M. J. H., \& Schiel, D. R. (2013). Artificial Spawning Habitats Improve Egg Production of a Declining Diadromous Fish, Galaxias maculatus (Jenyns, 1842). Restoration Ecology, 21(6), 686-694. doi:10.1111/rec.12008

Hickford, M. J. H., \& Schiel, D. R. (2016). Otolith microchemistry of the amphidromous Galaxias maculatus shows recruitment to coastal rivers from unstructured larval pools. Marine Ecology Progress Series, 548, 197207. doi:10.3354/meps11701

Hohn, C., \& Petrie-Hanson, L. (2013). Evaluation of visible implant elastomer tags in zebrafish (Danio rerio). Biology Open, 2(12), 1397-1401. doi:10.1242/bio.20136460

Jacquemin, S. J., \& Pyron, M. (2013). Effects of Allometry, Sex, and River Location on Morphological Variation of Freshwater Drum Aplodinotus grunniens in the Wabash River, USA. Copeia(4), 740-749. doi:10.1643/Ci-13-022

Jellyman, P. G., \& Harding, J. S. (2014). Variable survival across low pH gradients in freshwater fish species. J Fish Biol, 85(5), 1746-1752.

doi:10.1111/jfb.12497 
Jensen, H., Bohn, T., Amundsen, P., \& Aspholm, P. E. (2004). Feeding ecology of piscivorous brown trout (Salmo trutta L.) in a subarctic watercourse. Annales Zoologici Fennici, 41, 319-328.

Jowett, I. G. (2002). In-stream habitat suitability criteria for feeding inanga (Galaxias maculatus). New Zealand Journal of Marine and Freshwater Research, 36, 399-407.

Jung, C. A., Barbee, N. C., \& Swearer, S. E. (2009). Post-settlement migratory behaviour and growth-related costs in two diadromous fish species, Galaxias maculatus and Galaxias brevipinnis. Journal of Fish Biology, 75(3), 503-515. doi:10.1111/j.1095-8649.2009.02275.x

Kovac, V. (2006). Ontogenetic variability in external morphology and microhabitat use of spirlin Alburnoides bipunctatus from the River Rudava (Danube catchment). Journal of Fish Biology, 68, 1257-1270.

Langerhans, R. B., \& Reznick, D. N. (2010). Ecology and evolution of swimming performance in fishes: predicting evolution with biomechanics. Fish locomotion: an eco-ethological perspective. doi:10.1201/b10190-8

Legendre, M., Cauty, G., \& Jalabert, B. (1992). A Comparative-Study on Morphology, Growth-Rate and Reproduction of Clarias-Gariepinus (Burchell, 1822), Heterobranchus-Longifilis Valenciennes, 1840, and Their Reciprocal Hybrids (Pisces, Clariidae). Journal of Fish Biology, 40(1), 59-79. doi:DOI 10.1111/j.1095-8649.1992.tb02554.x

Lucas, M. C., Baras, E., Thom, T.J., Duncan, A., Slavik, O. (2001). Migration of freshwater fishes (B. Science Ed.): Blackwell Science.

Mccoy, W. (2006). Size correction: comparing morphological traits among populations and environments. Oecologia, 148(4), 547-554. doi:10.1007/s00442-006-0403-6

McDowall, R., \& Suren, A. (1995). Emigrating larvae of koaro, Galaxias-brevipinnis gunther (Teleostei, Galaxiidae), from the Otira River, New Zealand. New Zealand Journal of Marine and Freshwater Research, 29(2), 271-275. 
McDowall, R. M. (1968). Galaxias maculatus (Jenyns), the New Zealand Whitebait. Fisheries Research Bulletin No. 2 (New Series), 1-84.

McDowall, R. M. (2010). Why be amphidromous: expatrial dispersal and the place of source and sink population dynamics? Reviews in Fish Biology and Fisheries, 20(1), 87-100. doi:10.1007/s11160-009-9125-2

McDowall, R. M., \& Croom, H. (1988). Diadromy in fishes. River Research and Applications, 6(3), 235-236.

Mesters, C. M. L. (1990). The Impact of Eutrophication and Pollution on the Aquatic Vegetation of Rivers and Streams. 8th International Symposium on Aquatic Weeds, 161-162.

Milano, D., Lozada, M., \& Zagarese, H. E. (2010). Predator-induced reaction patterns of landlocked Galaxias maculatus to visual and chemical cues. Aquatic Ecology, 44(4), 741-748. doi:10.1007/s10452-010-9312-1

Milano, D., Ruzzante, D. E., Cussac, V. E., Macchi, P. J., Ferriz, R. A., Barriga, J. P., . . Walde, S. J. (2006). Latitudinal and ecological correlates of morphological variation in Galaxias platei (Pisces, Galaxiidae) in Patagonia. Biological Journal of the Linnean Society, 87(1), 69-82. doi:DOI 10.1111/j.10958312.2006.00556.x

Miles, J., \& Shevlin, M. (2001). Applying Regression and Correlation: SAGE Publications Ltd.

Myers, G. S. (1949). Usage of anadromous, catadromous and allied terms for migratory fishes. Copeia, 89-97.

Neuswanger, J., Wipfli, M. S., Rosenberger, A. E., \& Hughes, N. F. (2014). Mechanisms of drift-feeding behavior in juvenile Chinook salmon and the role of inedible debris in a clear-water Alaskan stream. Environmental Biology of Fishes, 97(5), 489-503. doi:10.1007/s10641-014-0227-x

Perrie, A., Morar, S., Milne, J. R., \& Greenfield, S. (2012). River and stream water quality and ecology in the Wellington Region. States and trends, Publication No. GW/EMI-T-12/143. 
Persson, L., Andersson, J., Wahlstrom, E., Eklov, P. (1996). Size-specific interactions in lake systems: Predator gape limitation and prey growth rate and mortality. Ecology, 77(3), 900-911. doi:Doi 10.2307/2265510

Prestrud, P. (1991). Adaptions by the Arctic Fox (Alopex lagopus) to the Polar Winter. Arctic, 44(2), 132-138.

Reiss, P., \& Grothues, T. M. (2015). Geometric morphometric analysis of cyclical body shape changes in color pattern variants of Cichla temensis Humboldt, 1821 (Perciformes: Cichlidae) demonstrates reproductive energy allocation. Neotropical Ichthyology, 13(1), 103-112.

Richardson, J., Jowett, I., Smith, J., Christiansen, R., Christiansen, B. (2000). Native freshwater fish: Inanga comings and goings - what happens to the whitebait that do get away? Water and Atmosphere, National Institue of Water and Atmospheric Research, 8 (2), 6-7.

Rincon, P. A., Bastir, M., \& Grossman, G. D. (2007). Form and performance: body shape and prey-capture success in four drift-feeding minnows. Oecologia, 152(2), 345-355. doi:10.1007/s00442-006-0651-5

Sainmont, J., Andersen, K. H., Varpe, O., \& Visser, A. W. (2014). Capital versus income breeding in a seasonal environment. Am Nat, 184(4), 466-476. doi:10.1086/677926

Shima, J. S., McNaughtan, D., Geange, S. W., \& Wilkinson, S. (2012). Ontogenetic variation in site fidelity and homing behaviour of a temperate reef fish. Journal of Experimental Marine Biology and Ecology, 416, 162-167. doi:10.1016/j.jembe.2012.02.020

Shulman, G. E., \& Love, R. M. (1999). The biochemical ecology of marine fishes (Vol. 36): Academic Press, London.

Sindhe, V. R., \& Kulkarni, R. S. (2004). Gonadosomatic and hepatosomatic indices of the freshwater fish Notopterus notopterus (Pallas) in response to some heavy metal exposure. J Environ Biol, 25(3), 365-368.

Smith, J. (2015). Freshwater Fish Spawning and Migration Periods. MPI Technical Paper No: 2015/17, 1-86. 
Stevens, J. C., Hickford, M. J., \& Schiel, D. R. (2016). Evidence of iteroparity in the widely distributed diadromous fish inanga Galaxias maculatus and potential implications for reproductive output. J Fish Biol, 89(4), 1931-1946. doi:10.1111/jfb.13083

Strickland, R., \& Quarterman, A. (2001). Review of freshwater fish in the Wellington Region. Cawthron Report No. 669.

Taylor, M. J., Buckland, A. R., \& Kelly, G. R. (1992). South Island inanga spawning surveys, 1988 - 1990. New Zealand Freshwater Fisheries Report No. 133, 171.

Varpe, O., Jorgensen, C., Tarling, G. A., \& Fiksen, O. (2009). The adaptive value of energy storage and capital breeding in seasonal environments. Oikos, 118, 363-370.

Walker, J. A., Alfaro, M. E., Noble, M. M., \& Fulton, C. J. (2013). Body Fineness Ratio as a Predictor of Maximum Prolonged-Swimming Speed in Coral Reef Fishes. Plos One, 8(10). doi:ARTN e75422

10.1371/journal.pone.0075422

Weaver, M. E., \& Ingram, D. L. (1969). Morphological Changes in Swine Associated with Environmental Temperature. Ecology, 50(4), 710-\&. doi:Doi $10.2307 / 1936264$

Zeyl, J. N., Love, O. P., \& Higgs, D. M. (2013). Condition-dependent auditory processing in the round goby (Neogobius melanostomus): links to sex, reproductive condition and female estrogen levels. J Exp Biol, 216(Pt 6), 1075-1084. doi:10.1242/jeb.076935 